\title{
1 Holocene fire and vegetation dynamics in the Central Pyrenees
}

\section{2 (Spain)}

3 Maria Leunda ${ }^{(1)^{*}}$, Graciela Gil-Romera ${ }^{(1,2)}$, Anne-Laure Daniau ${ }^{(3)}$, Blas M. Benito ${ }^{(4)}$ Penélope

4 González-Sampériz ${ }^{(1)}$

5 (1) Department of Geoenvironmental Processes and Global Change, Pyrenean Institute of 6 Ecology (IPE-CSIC). Av/ Montañana s/n, 50059 Zaragoza, Spain

7 (2) Department of Geography and Earth Sciences, Aberystwyth University, Penglais Campus, 8 SY233DB, United Kingdom

9 (3) Environnements et Paléoenvironnements Océaniques et Continentaux, UMR CNRS 5805 EPOC, University of Bordeaux. Allée Geoffroy Saint-Hilaire.33615 Pessac, France

(4) Department of Biological Sciences (BIO). University of Bergen, Bergen, Norway

*Corresponding author: Maria Leunda (mleunda@ipe.csic.es; leunda.maria@gmail.com). Department of Geoenvironmental Processes and Global Change, Pyrenean Institute of Ecology 14 (IPE-CSIC). Av/ Montañana s/n, 50059 Zaragoza, Spain.

\section{Abstract}

Fire-vegetation relationships are critical to understand transient mountain ecosystems and their long-term landscape dynamics, which is essential for alpine forest conservation. In this paper we aim to 1 ) reconstruct the Holocene fire history at high altitudes of the southern Central Pyrenees, 2) add evidence to the debate on fire origin, naturally or anthropogenically produced, 3) determine the importance of fire as a disturbance agent for sub-alpine and alpine vegetation, in comparison with the plant community internal dynamics applying conditional 
23 inference trees. We present and compare microcharcoal and pollen data series, from two

24 lacustrine sedimentary sequences in the Central Pyrenees: Basa de la Mora (BSM), within the 25 treeline ecotone at the sub-alpine belt (1914 m a.s.I.) and Marboré Lake, above the treeline at 26 the alpine belt (2612 $m$ a.s.I.).

27 We evidence that, fire activity was not the most important factor in driving vegetation 28 dynamics regionally. Our results suggest that spatially, the fire signal might be site-dependent 29 while over time, climate exerted a strong influence on fire activity during the early-to-mid 30 Holocene, showing more fires during the Holocene Thermal Maximum (HTM) (ca. 7000-6000 31 cal yr BP) whereas fire activity decreased with the cold Neoglacial period. At ca. 3700 cal yr BP, 32 fire activity increased coinciding with a regional landscape opening, suggesting that human 33 activities may have strengthened the importance of fire. Fire activity remained low over the 34 last two millennia but a remarkable Holocene maximum for the last centuries in both 35 sequences is observed, likely related to increasing human pressure.

Key words: Microcharcoal, pollen, lake sediments, palaeoclimate, human impact, fire-history 
Fire is a relevant disturbance of the Earth system, driving significant changes in ecosystem structure and function, species evolution, biomass dynamics or global carbon cycling (Bond and Midgley, 1995; Bowman et al., 2009; Pausas and Schwilk, 2012; Archibald et al., 2013). Fire regimes are driven by factors such as climate (e.g. Daniau et al., 2012), vegetation through fuel load, connectivity or flammability, soil types, ignition sources-natural or anthropogenic-, and topographical features (Whitlock et al., 2010; Krawchuk and Moritz, 2011). Thus, the sensitivity of any ecosystem to fire depends on its own characteristics.

Sub-alpine and alpine plant communities are formed by alpine pastures and weakly flammable conifer woodlands like Pinus sylvestris L., Pinus uncinata Ramond ex DC, Juniperus communis L. and Abies alba Mill, which hold no post-fire strategy, especially after crown fires (Keeley et al., 2012). Fire in mountains is associated with the occurrence of woody species (Leys et al., 2014), and is therefore infrequent above the treeline due to the lack of arboreal biomass. Under natural conditions, fire occurrence will generally be controlled by the fuel moisture degree, in turn driven by precipitation and temperature.

The high landscape heterogeneity in mountain areas often implies different fire behaviour (Leys and Carcaillet, 2016; Fréjaville et al., 2018) at the sub-regional or local scales. Mountain environments are in addition very sensitive to climate, fire, and land use changes, because of their narrow tolerance capabilities, especially at the boundaries of the treeline (Theurillat and Guisan, 2001; Pauli et al., 2012).

Fire occurrence is generally low in alpine ecosystems under present climatic conditions and land use patterns in the Pyrenees. However, fire activity has changed over time (JiménezRuano et al., 2019) and may have been a more frequent disturbance over the last millennia, with different climatic settings and more intense human activities. In fact, human activities have been modifying natural fire regimes through changing land use (Pausas and Keeley, 2014) 
since centuries or even millennia (Carracedo et al., 2017; Morales-Molino et al., 2017), using fire as a tool in land management. For instance, during the mid- $19^{\text {th }}$ century humans used fire as a common tool to maintain opened mountain landscapes in the Pyrenees (García-Ruiz et al., 2015; García-Ruiz and Lasanta, 2018), modifying the structure of sub-alpine systems. However, due to the abandonment of traditional land uses, the extension of opened areas has been reduced, increasing forest connectivity and the accumulation of standing fuel loads. Consequently, the increase in drought conditions and temperature due to global warming (IPPC, 2014), together with the increase in the amount of standing fuel may enhance the risk of wildfires in southern European mountains (Ryan, 2000; Wastl et al., 2013). This may reduce forest resilience to wildfires (Stevens-Rumann et al., 2018), while it can also provide an opportunity for ecosystem restoration under particular circumstances (Leverkus et al., 2019).

Understanding to what extent changing fire regimes at longer temporal scales have contributed to the current mountain landscapes is paramount for designing sustainability policies for socio-ecological systems. In this context, long-term ecology research emerges as a critical tool to obtain the needed time series to address environmental changes at centennial to millennial time-scales. Sedimentary microcharcoal analysis improves our understanding on the long-term role of fire as a key ecological factor (Whitlock and Larsen, 2001; Power et al., 2008; Colombaroli et al., 2010; Feurdean et al., 2012), whereas pollen analysis in sediments has been widely used for the study of vegetation changes (Carrión et al., 2010; and references therein Birks and Björn, 2018). Both proxies have facilitated and strengthened our understanding of past disturbances in the landscape.

The comparison of different charcoal records at global scale has revealed significant regional differences in fire activity during the Holocene, probably caused by the complex interplay between climate, vegetation and human impact (Power et al., 2008; Vannière et al., 2011, 2016; Marlon et al., 2013). Thus, despite climate seems to be the main fire driving force at 
large spatial scales in fire-prone areas, regional studies evidence that other local factors would be also determining the high temporal variability in biomass burning (e.g. Gavin et al., 2006; Feurdean et al., 2012, 2017; Leys and Carcaillet, 2016). Given this spatial and temporal heterogeneity in variables controlling fire, site-specific histories are needed to show how fire activity has been modulated by microclimate, vegetation, topography and land-use (Gavin et al., 2006; Whitlock et al., 2010; Rius et al., 2011).

Apart from fire, climate and other external disturbances, plant population dynamics are also determined by the ecological memory of a community, defined as the capacity of past states of the system to influence present or future responses (Padisak, 1992; Ogle et al., 2015). In this regard, antecedent taxa dynamics and fire activity may also be relevant explaining the abundance of a taxa at a given time. Therefore, understanding ecological memory may help to assess long-term ecosystem resilience.

Contrary to other European mountain ranges, where long-term fire activity has been widely studied in mountain sites (e.g. Tinner et al., 1998, 2015; Blarquez and Carcaillet, 2010; Colombaroli et al., 2010; Feurdean et al., 2012; Leys et al., 2014; Florescu et al., 2018), we know little about the long-term fire history of the Iberian Peninsula mountain ranges (PérezObiol et al., 2012; Carracedo et al., 2017; Morales-Molino et al., 2017) and, in particular, of the Pyrenean mountains. While most studies focus on the eastern part (Ejarque et al., 2010; Bal et al., 2011; Pérez-Obiol et al., 2012; Cunill et al., 2013; Garcés-Pastor et al., 2017) presenting the evolution of fire activity during the Lateglacial and Holocene periods very few have been developed at the central part (Gil-Romera et al., 2014), and little is known about the role of fire transforming alpine ecosystems.

In the current research we aim to 1) reconstruct the long-term fire history in the southern Central Pyrenees, 2) add evidence to the debate on fire origin, naturally or anthropogenically driven, comparing our Holocene fire series with other local and regional evidence, and 3) 
compare the relative influence of antecedent values of pollen abundance and fire activity

121 versus concurrent fire activity on the dynamics of several taxa. We present an encompassing comparison of well-dated Holocene sedimentary charcoal records and their fossil pollen assemblages from the sub-alpine, Basa de la Mora Lake (BSM) (at the treeline) and alpine Marboré Lake (MAR) (above the treeline).

\section{Regional setting}

The Pyrenees are a mountain range located in north eastern Iberian Peninsula (Fig. 1a), between the Atlantic Ocean and the Mediterranean Sea. Water availability in the Pyrenees is controlled by an important west-east rainfall gradient (2000 to $1000 \mathrm{~mm}$ ) driven by the North Atlantic Oscillations (Araguas-Araguas and Díaz Teijeiro, 2005). The western Pyrenees have a direct Atlantic influence with a humid climate, while the eastern Pyrenees have a stronger Mediterranean influence, with a drier and warmer season. Beyond these general features, there is also a high-climatic variability controlled by topography and elevation, with highest mean annual precipitation (MAP) values occurring at the highest elevations (2000$2500 \mathrm{~mm}$ ), and a temperature lapse rate of ca. -0.60/100 m (García-Ruiz et al., 2015) with a mean annual temperature gradient that goes from 5-10 으, in the valleys to below 0 으 in the high massifs (Ninyerola et al., 2005) (Fig. 1b).

The altitudinal gradient defines the main vegetation belts in the Pyrenees (Fig. 2). The low montane community (ca. 1200-1400 m a.s.l.) is characterized by mosaics of croplands and open mixed areas of Quercus ilex L., Quercus faginea Lam. /cerrioides Willk. \& Costa, P. sylvestris with a dense shrub land of different juniper species, Buxus sempervirens L. and Genista scorpius (L.) DC. among others. The upper montane community (ca. 1400-1600 m a.s.l.) features well-developed broadleaf forests mainly composed by Corylus avellana L., Betula pendula Roth, Fraxinus excelsior L., Acer campestre L., Sorbus aria (L.) Crantz, Sorbus 
$\mathrm{m}$ a.s.l.) is dominated by coniferous forests of $P$. uncinata with sparse shrubs like J. communis or Rhododendron ferrugineum L. Although slope orientation, soil formation, microclimate and past human activities interact to determine the upper limit of the closed forest, the timberline is located at ca. $1800-1900 \mathrm{~m}$ a.s.I. Both timberline and treeline (up to ca. $2000-2200 \mathrm{~m}$ a.s.l.) are communities where the dominant tree is $P$. uncinata (Fig. 2). Alpine and sub-nival communities (higher than ca. $2000 \mathrm{~m}$ a.s.l.) are formed by alpine herbs and dwarf shrubs.

Fires in the Pyrenees occur mostly in forested areas (Cubo et al., 2012; Vázquez de la Cueva, 2016) and they are mostly naturally produced, triggered by lightning as the main ignition source in high altitude locations (Amatulli et al., 2007; Cubo et al., 2012; Vázquez de la Cueva, 2016), during summer storms (Font, 1983; Vázquez de la Cueva, 2016). Despite human-caused fires do happen as well, these take place in the more fragmented areas in the montane zone (Amatulli et al., 2007).

MAR is an alpine glacial lake located at $2612 \mathrm{~m}$ a.s.l. at the base of the Monte Perdido Glacier (Fig. 1c). BSM (1914 m a.s.I.) is a shallow glacial lake located on the north-facing slope of the Cotiella Peak (Fig. 1d). Although both lakes in this study lay at the Central Pyrenees and are ca. $30 \mathrm{~km}$ from each other, each lake presents quite different geographical and ecological characteristics summarized in Table 1. MAR does not present woody vegetation around the lake, as it is placed in the alpine belt. The treeline is located $600 \mathrm{~m}$ below, thus, fires are less likely locally. However, BSM is currently located in the sub-alpine belt, and thus, within the treeline ecotone dominated by $P$. uncinata communities. Fires can potentially occur in the vicinity of the lake, although fire activity is nowadays low in this place. Furthermore, the modern fire activity at a regional scale in both areas is weak, with ca. 1 to 2 fire events occurring every 30 years, invariably set by natural causes (mostly summer storms) that, however, often create mid-to-large fires with a burnt area between 10-100 Ha (Vázquez de la Cueva, 2016). 


\section{Materials and Methods}

\subsection{Lake-coring, chronology and pollen analysis}

Previous multiproxy analyses of both sedimentary records have already been published, PérezSanz et al. (2013) for BSM Lake and Leunda et al. (2017) and Oliva-Urcia et al. (2018) for MAR Lake. In the present study we focus on the Holocene section of both sequences. BSM depthage model is based on $13{ }^{14} \mathrm{C}$ terrestrial plant macrofossil ages along $11 \mathrm{~m}$ depth (mean sedimentation rate: $0,149 \mathrm{~cm} / \mathrm{yr}$ ), and MAR depth-age model is based on $9{ }^{14} \mathrm{C}$ bulk sediment dates along $6 \mathrm{~m}$ depth (mean sedimentation rate: 0,061 cm/yr). In both cases, the most recent part has been dated with ${ }^{210} \mathrm{~Pb} /{ }^{137} \mathrm{Cs}$. Depth-age models were carried out with Clam 2.2 software (Blaauw, 2010) using linear interpolation between dated levels (Fig. 3). Pollen analysis for both sequences was conducted in Pérez-Sanz et al. (2013) and Leunda et al. (2017) following the standard chemical procedure (Moore et al., 1991) but including Thoulet solution $\left(2.0 \mathrm{~g} / \mathrm{cm}^{3}\right)$ for separation and Lycopodium clavatum spores to calculate concentration (Stockmarr, 1971). Pollen has been identified under a light microscope, and using the reference collection from the Pyrenean Institute of Ecology (IPE-CSIC), determination keys and photo atlases (Moore et al., 1991; Reille, 1992). Results have been calculated both in

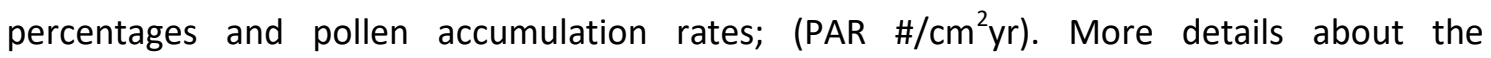
chronological framework and pollen analysis are provided in Pérez-Sanz et al. (2013) and Leunda et al. (2017).

\subsection{Microcharcoal analysis}

We present here microcharcoal series for BSM and MAR as fire proxy, aiming to achieve our first objective, i.e. to reconstruct the long-term regional fire activity. The term microcharcoal refers to small carbonized particles (Fig. S1) produced during vegetation fires (Jones et al., 

1997) and transported by aeolian and fluvial agents from the combustion site to the sedimentation basin. In lakes charcoal preserves well due to its relatively high resistance to chemical and microbial decomposition (Habib et al., 1994; Hart et al., 1994; Verardo, 1997; Hockaday et al., 2006; Quénéa et al., 2006).

Microcharcoal analyses were carried out in a total of 108 samples for MAR and 130 samples for BSM. We sampled microcharcoal at the same depths of the pollen samples previously analysed. In BSM sample resolution was every $5 \mathrm{~cm}$ with a mean temporal resolution between samples ca. 70 years, while MAR sampling was performed every 5-10 cm with a mean temporal resolution between samples ca. 109 years, except for the upper part, where sampling was every $2 \mathrm{~cm}$. Sediment samples were processed using the chemical procedure following Daniau et al. $(2009,2013)$ at the UMR-EPOC laboratory (CNRS-Université de Bordeaux). The microcharcoal extraction technique consisted of a chemical treatment of $37 \%$ $\mathrm{HCl}, 68 \% \mathrm{HNO}_{3}$ and $33 \% \mathrm{H}_{2} \mathrm{O}_{2}$ performed over $24 \mathrm{~h}$ on $0,3 \mathrm{~g}$ of dried sediment, followed by a dilution of 0,1 applied to the residue. The suspension was then filtered onto a cellulose acetate membrane containing nitrocellulose of $0,45 \mu \mathrm{m}$ porosity and $47 \mathrm{~mm}$ in diameter. A portion of this membrane was mounted onto a slide.

The identification and quantification of microcharcoal was performed using automated image analysis with an automated Leica DM6000M microscope at x500 magnification in transmitted light and following the criteria proposed by Boulter (1994), identifying charcoal as being black, opaque and angular with sharp edges. This technique, allows identifying microcharcoal particles automatically, once colour and lightning settings are established for identifying them, reducing considerably the counting task. Identification of unburned particles, characterized by the absence of plant structures and distinct level of reflectance, was used to set the best-fit threshold level to secure identification of microcharcoal by image analysis. Critical particles were distinguished from dark minerals by reflected light (Clark, 1984) and in order to have a 
good statistical representation of each sample, 200 view fields (200 images) of $0.0614 \mathrm{~mm}^{2}$ were taken in colour with a $1044 \times 772$ pixels digitizing camera ( 1 pixel $=0.276 \mu \mathrm{m}$ ). The surface scanned by the microscope represented a surface area of $12.279 \mathrm{~mm}^{2}$. Although this technique has primarily been applied in marine sediments (Daniau et al., 2009, 2013) it has also been successfully used for lake sediments (e.g. Tinner et al., 1999; Leys et al., 2014; Remy et al., 2018). Microcharcoal particles below $10 \mu \mathrm{m}$ have not been considered, as theoretical considerations showed that particles smaller than 5-10 $\mu \mathrm{m}$ in diameter are difficult to identify (Clark, 1988).

From the microcharcoal measurements, three parameters were calculated for each sample: (i) the concentration of microcharcoal (CCnb: \#/g); (ii) the concentration of microcharcoal surface (CCs), which is the sum of all surfaces of microcharcoal in one sample per gram $\left(\mu \mathrm{m}^{2} / \mathrm{g}\right)$ and (iii)

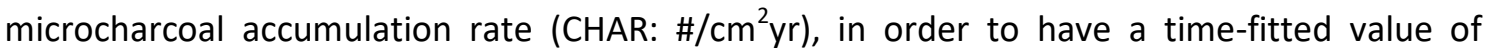
charcoal. $1 \mathrm{~cm}^{3}$ of sediment was sampled with a syringe and weighted $(\mathrm{g})$ in order to calculate sediment density $\left(\mathrm{g} / \mathrm{cm}^{3}\right)$ and multiply it with charcoal concentration $(\# / \mathrm{g})$ and sedimentation rate $(\mathrm{cm} / \mathrm{yr})$ to obtain microcharcoal accumulation rate $\left(\# / \mathrm{cm}^{2} \mathrm{yr}\right)$. each. For this replicate samples, the mean value and standard deviation was calculated. For the comparison of both sequences, microcharcoal influx data was normalized with Z-scores (Glantz et al., 2016).

\subsection{Numerical analyses: conditional inference trees}

Accomplishing the third objective of our research implied estimating to what extent long-term fire dynamics is a relevant variable shaping the sub-alpine and alpine Pyrenees landscape. We

241 thus calculated the effect that antecedent and concurrent fires (CHAR), have on the 242 abundance of certain taxa (PAR). On the other hand, we intend to quantify to what extent PAR 243 itself is determined by its own antecedent values. In doing so, we incorporate a quantitative 
approach to the ecological memory concept (Ogle et al., 2015). In order to analyse the effect of past and concurrent CHAR and past PAR on each PAR value, we aligned the samples of each site with their antecedent ones, generating a data structure with a lag of order 1 , following the model expressed in Equation 1:

Equation 1: PAR CHAR + CHAR.antecedent + PAR.antecedent

PAR is the response, with the same age and depth as CHAR which represents concurrent fire, while CHAR.antecedent and PAR.antecedent have the age and depth of the previous sample, and represent the effect of past states on the dynamics of the system.

PAR values of Pinus, Abies, Betula, Corylus, and Herbs were used as response variable for both sites. Deciduous Quercus was only modelled in BSM because MAR records very low and sparse Quercus PAR values.

The models were fitted with conditional inference trees (Hothorn et al., 2006) through the ctree function of the R package partykit (Hothron and Zeileis, 2015). Conditional inference trees are recursive partition models that use a permutation test to find on each iteration the threshold of any predictive variable that better splits the data into two homogeneous partitions. The process is repeated on each data partition until further data splitting is not possible, or the terminal nodes of the recursive partition tree reach a minimum sample size. hierarchy are more important to explain patterns in the data than variables located in lower nodes. Regression trees are easy to interpret, represent partial interactions among predictive variables, and do not rely on assumptions about the properties of the data in the way linear models do. Despite the fact that they are generally underused in ecology, conditional inference trees have proved to be extremely useful in conservation biology (Johnstone et al., 2014).

\section{Results}




\subsection{Temporal trends in microcharcoal records}

269

270

271

272

273

275

276

277

278

279

280

281

282

283

284

286

287

288

289

290

291

Variations in microcharcoal concentrations (CCnb and CCs) in each lake show very similar fluctuations (Fig. S2). This confirms that both CCnb and CCs record the same pattern of microcharcoal concentration variability, suggesting that there is no microcharcoal overrepresentation as the result of potential fragmentation during particle production or transport and thus, both units could be used to interpret the fire record (Daniau et al., 2012). CHAR values (microcharcoal influx) also follow similar concentration variability in both sequences (Fig. S2).

\subsubsection{MAR Lake microcharcoal sequence}

The beginning of the sequence shows a low microcharcoal influx between ca. 9500-7000 cal yr BP (mean influx of $9 \times 10^{4}$ particles $/ \mathrm{cm}^{2} \mathrm{yr} ;{ }^{\text {SD }} 2.3 \times 10^{4} \# / \mathrm{cm}^{2} \mathrm{yr}$ ). Microcharcoal increases from 7000-6500 and 6200-5700 cal yr BP (mean influx of $1.7 \times 10^{5}$ particles/cm ${ }^{2} \mathrm{yr}$; ${ }^{\text {SD }} 3.9 \times 10^{4}$ particles/ $\mathrm{cm}^{2} \mathrm{yr}$ ). A significant decrease is appreciated from 5700-3600 cal yr BP (mean influx of $1 \times 10^{5}$ particles $/ \mathrm{cm}^{2} \mathrm{yr} ;{ }^{\text {SD }} 2.8 \times 10^{4}$ particles $/ \mathrm{cm}^{2} \mathrm{yr}$ ). Fluctuating CHAR values are found between 3600 and 1600 with several local maxima (up to an influx value of $2.6 \times 10^{5}$ particles $/ \mathrm{cm}^{2} \mathrm{yr}$ ). The signal becomes weak between $1600-1000 \mathrm{cal}$ yr BP but an abrupt and consistent charcoal increase is observed afterwards until present day, reaching maximum values (maximum influx value $3.1 \times 10^{5}$ particles $/ \mathrm{cm}^{2}$ yr) (Fig. S2 and Fig. 4a).

\subsubsection{BSM Lake microcharcoal sequence}

At BSM, low but fluctuating values are present during 9500-6600 cal yr BP (mean influx $1.6 \times 10^{5}$ particles $/ \mathrm{cm}^{2} \mathrm{yr} ;{ }^{\text {SD }} 2 \times 10^{5}$ particles $/ \mathrm{cm}^{2} \mathrm{yr}$ ) with a significant microcharcoal peak at ca. $6700 \mathrm{cal}$ yr BP (microcharcoal influx of $2.2 \times 10^{5}$ particles $/ \mathrm{cm}^{2} \mathrm{yr}$ ). Subsequently, the signal is weakened with sustained low microcharcoal values until ca. 3700 cal yr BP (mean influx $5.4 \times 10^{4}$ particles $/ \mathrm{cm}^{2} \mathrm{yr} ;{ }^{\text {SD }} 2.4 \times 10^{4}$ particles $/ \mathrm{cm}^{2} \mathrm{yr}$ ), where it increases showing a marked isolated 
maximum (microcharcoal influx of $2.2 \times 10^{5}$ particles $/ \mathrm{cm}^{2} \mathrm{yr}$ ). Microcharcoal signal maintains low afterwards, until almost recent times (mean influx $4.4 \times 10^{4}$ particles $/ \mathrm{cm}^{2} \mathrm{yr}$; ${ }^{\text {SD }} 2.3 \times 10^{4}$ particles $/ \mathrm{cm}^{2} \mathrm{yr}$ ) with the exception of a minor fire peak ca. $1200 \mathrm{cal} \mathrm{yr}$ BP. The maximum microcharcoal signal is found for the last decades (up to an influx value of $2.4 \times 10^{5}$ particles/cm² yr) (Fig. S2 and Fig. 4g).

\subsection{Conditional inference trees}

Conditional inference trees (Fig. 5 and Fig. S3 for all taxa and sites) found significant patterns of influence of the explanatory variables we have used (antecedent PAR, antecedent CHAR and CHAR) on PAR, except in the case of Pinus and Betula in MAR (Fig. S3a,b). For most taxa, PAR.antecedent, which represents the endogenous dynamics of the taxa, is the best explanatory variable (Fig. 5a,c,d,e,f and Fig. S3c,d,e). Hence, larger values of antecedent PAR seem to have a positive effect on the taxa's abundance, at any given time, especially in BSM. Antecedent CHAR had a significant and positive effect on Quercus PAR in BSM (Fig. 5f), while concurrent CHAR influenced positively the pollen abundance of Abies and Corylus in MAR (Fig. $5 a, b)$. The boxplots represent mean values of each PAR series classified according to the explanatory variables. For instance, looking at Abies MAR (Fig. 5a), abies.antecedent is the best explanatory variable determining large Abies values (right boxplot), only when abies.antecedent is low, concurrent CHAR succeeds predicting Abies PAR to a certain threshold, producing the next classified group (central boxplot).

\section{Discussion}

\subsection{Pollen and microcharcoal source: considerations for the studied sequences}

Comparing these two sequences brings forward the need to look at site-specific settings, as these might be determining different fire behaviour and, what it is most important, source area for biological proxies and transport pathways (Corella et al., 2018). The study sites are 
defined by both catchment dimensions and altitude, thus, several studies have evidenced that higher elevations may record best regional rather than local environmental variations (Escudero et al., 2016; Corella et al., 2018).

MAR (2612 m a.s.l.) is placed ca. $600 \mathrm{~m}$ higher than the current treeline (Figs. $1 \mathrm{c}$ and 2), and we infer that due to the absence of tree macrofossils along the sedimentary sequence (Leunda et al., 2017), the treeline would have not reached the Marboré cirque during the Holocene. Moreover, MAR lies in an open cirque wind-exposed supporting that the source area of both arboreal pollen and microcharcoal particles would come from large areas both from northern and southern slopes of the Pyrenees, having a wide catchment area and thus registering fires and vegetation dynamics from far. Indeed, regional tropospheric circulation becomes a more important factor in particle transport and deposition above ca. $2100 \mathrm{~m}$ a.s.l., whereas below this altitude horizontal regional transport is less patent (Escudero et al., 2016).

On the other hand, BSM is currently located in the sub-alpine belt (1914 m a.s.l.) at the treeline ecotone (Figs. 1d and 2). During the Holocene the lake would have been likely colonized by different forest communities (Pérez-Sanz et al., 2013), enabling fires to also occur locally. Thus, the source area of both tree pollen and microcharcoal could be partially a background signal but still more local than in MAR, with an important input from nearby forest communities.

\subsection{Fire history through the Holocene in the Central Pyrenees}

\subsubsection{Low fire activity during the early Holocene (ca. 9500-7000 cal yr BP)}

Fire activity was relatively low during the early Holocene, as inferred from both BSM and MAR sequences, although they show differing patterns; MAR holds a lower variability compared to BSM which evidences a fluctuating fire activity (Fig. 4a,g). A rather low fire activity is also detected in other Pyrenean sequences (Cunill et al., 2013; Gil-Romera et al., 2014; Garcés- 

pine pollen; Fig. 4b,h), and despite the lack of treeline reconstructions for the early Holocene in the Pyrenees, Cunill et al. (2013) demonstrated the existence of pine biomass at $2200 \mathrm{~m}$ a.s.I. in the eastern Pyrenees, which could mean that BSM could already be surrounded by pines. On the other hand, the importance of mesophytes (mainly Corylus and Betula) is clear in the MAR sequence, similar to more Atlantic sites like El Portalet (González-Sampériz et al., 2006; Gil-Romera et al., 2014). In this regard, significant differences in vegetation composition have been recorded along the Pyrenees during the early Holocene related to the more Atlantic (González-Sampériz et al., 2006; Gil-Romera et al., 2014; Leunda et al., 2017) vs. more Mediterranean influence (e.g. Miras et al., 2007; Pérez-Obiol et al., 2012; Pérez-Sanz et al., 2013; Connor et al., 2019).

Thus, the different patterns between BSM and MAR in terms of fire activity could be related to the differences in biomass type and availability and to the lake's geographical settings, which today is characterized by different amounts of rainfall (Fig. 1b). Especially, the rainfall gradient has a critical effect on the landscape flammability as, if biomass is available, dry settings will more easily become flammable. This would have been the case in BSM, located at a denser vegetated, drier and more continental lower altitude (Pérez-Sanz et al., 2013) compared to the alpine, locally wetter MAR site.

Even if fire severity and extent is difficult to infer from microscopic charcoal data alone, pollen assemblages variation (e.g. an increase in herbaceous pollen taxa) can be used as indirect evidence for high severity fires (Minckley and Shriver, 2011). As there are no evidences of landscape opening in terms of herb expansion, it is likely that these fires did not play a significant role in vegetation dynamics. In addition to this, no human occupation signs have been detected for the Central Pyrenees at this period. The livelihood of Mesolithic (11700$7800 \mathrm{cal}$ yr BP) people was hunting-gathering in small nomadic groups (Valdeyron et al., 2008; 
Ejarque et al., 2010), which implies weak environmental imprints (Montes et al., 2016; RojoGuerra et al., 2018).

\subsubsection{Increasing fire activity at HTM (ca. 7000-5500 cal yr BP)}

Fire activity increased over the mid-Holocene in both sequences. MAR records an earlier increase starting at ca. $7000 \mathrm{cal}$ yr BP and, although fluctuating, lasting until ca. $5500 \mathrm{cal}$ yr BP (Fig. 4a), whereas the increase in fire activity in BSM occurs at ca. 6700 cal yr BP (Fig. 4g). Other eastern Pyrenean sequences such as in Estanilles peatbog also show a fire increase (Pérez-Obiol et al., 2012).

The expansion of mesophytes (especially Betula, deciduous Quercus and Corylus) in BSM occurred during the mid-Holocene (8200-5500 cal yr BP; Fig. 4 j,k), when Betula could have reached the sub-alpine belt (Pérez-Sanz et al., 2013; Leunda et al., 2019). The treeline, mainly composed by Pinus, would have reached the highest levels during this period (Cunill et al., 2013; Leunda et al., 2019). This biomass expansion has been closely related to a summer temperature increase. In fact, the chironomid based July temperature reconstruction for the Holocene in BSM, shows that the maximum summer temperatures occurred between 8000 6500 cal yr BP (Fig. 4n) which is in agreement with other European summer temperature reconstructions defining the HTM (Renssen et al., 2009; Samartin et al., 2017). Thereby, favourable climate conditions for burning established supported by the constant and increasing biomass availability. Nevertheless, fires were probably neither intense nor virulent, since vegetation does not show important changes.

In addition to this, scatter Neolithic archaeological sites have been found at lower elevations in the Central Pyrenees where sparse fumier levels (succession of animal manure, soil and plant remains, which besides being naturally fermented, were sometimes burned to sanitize the enclosure (Alday et al., 2012; Montes and Alday, 2012) were identified (Figs. 1a and 60). However, no pollen evidence for agro-pastoral activities are detected in MAR and BSM nor in 
the nearby palaeoenvironmental sequences at this time (González-Sampériz et al., 2017).

Nevertheless, a rather early human impact with punctual presence of cereal pollen grains since the Neolithic onset (ca. 7000 cal yr BP) or even earlier (Ejarque et al., 2010; Pérez-Obiol et al., 2012) has been detected in the eastern Pyrenean palaeoenvironmental sequences, where sparse sub-alpine Neolithic settlements were found (Gassiot Ballbè et al., 2014; Gassiot Ballbè, 2016).

Thus, even if it is not possible to discard punctual anthropogenic burning practices during the Neolithic period, it is not likely that they would leave a large imprint at high altitude sites as evidences for human presence occur locally at lower altitudes (González-Sampériz et al., 2019). Thus, the driving mechanism for the increase in fire activity at both sites at ca. $7000 \mathrm{cal}$ yr BP might be related to both biomass availability and increasing summer temperatures.

\subsubsection{Fire activity decline during the Neoglacial period (ca. 5500-3700 cal yr BP)}

402

403

404

405

406

407

Both in BSM and MAR there's a general fire activity decline concurrent at regional (Rius et al., 2011; Garcés-Pastor et al., 2017) and subcontinental scales (Vannière et al., 2011) at ca. 5700 cal yr BP (Fig. 4a,g). Wildfire weakening coincides with the beginning of the Neoglacial period (Davis et al., 2009; Kumar, 2011) where a glacier expansion occurred at ca. $5100 \pm 100$ cal yr BP, in both southern (García-Ruiz et al., 2014) and the northern (Gellatly et al., 1992) slopes of the Central Pyrenees. We lack an independent temperature reconstruction for $6000-4200$ cal yr BP period due to low chironomid contents in BSM. However, during the late-Holocene (4200-2000 cal yr BP) inferred temperatures were the lowest through the Holocene (Fig. 4n; Tarrats et al., 2018).

A lower proportion of archaeological settlements were present in Central Pyrenees at this time (Fig. 40), as societies may have also been affected by the wetter/cooler oscillations of the Neoglacial period. Rius et al. (2011) also indicated fewer signs of human activities at the 
northern slope of the Pyrenees. This scenario suggests that climatic control is still dominant in promoting fire occurrence during the mid-to-late-Holocene transition.

Simultaneously, Abies spread from ca. 6000 cal yr BP in both BSM and MAR (Fig. 4c,i) and in other Pyrenean records (Miras et al., 2007; Pérez-Sanz et al., 2013; Garcés-Pastor et al., 2017). Abies is a mesophilous, late-successional tree species very shade tolerant and considered to prefer cool and moist sites (Villar et al., 1997). Different studies have also demonstrated that Abies is a fire sensitive taxon, being negatively affected by fire activity (Tinner et al., 1999; Schwörer et al., 2015). So, we argue that the fir spread could be favoured by both the temperature descent and a weaker fire activity until ca. 3500 cal yr BP (Fig. 4a,g). pattern as other Pyrenean sequences (González-Sampériz et al., 2006; Miras et al., 2007; Pèlachs et al., 2007; Pérez-Sanz et al., 2013; Garcés-Pastor et al., 2017; Leunda et al., 2017), very likely related to these changing climatic conditions.

A great increase in fire activity is appreciated in both sequences; at ca. 3700 cal yr BP in BSM, followed by the rise in MAR between 3500-3000 cal yr BP. In regard to the eastern Pyrenean palaeoenvironmental sequences, a general intensification of fire occurrence is observed for the last ca. 4000 years, with an alternation of higher and lower periods of fire activity, denoting spatial and temporal disparities in fire activity (Bal et al., 2011; Rius et al., 2011; cal yr BP onwards, indicating the occurrence of fires. 
not provoke important biomass losses, contrarily to what may have occurred over the last ca. 3700 years. Abies decreased (Fig. 4c,i), suggesting again that fir's populations may have been negatively affected by fires.

441 Regarding climatic factors, reconstructed summer temperatures in the area are the lowest for 442 the whole Holocene (Fig. 4 ; Tarrats et al., 2018), which apparently may have not favoured fire 443 occurrence. A decoupling of fire and climatic control has been attributed to human impact, 444 overriding the effect of natural ignition in alpine ecosystems (Colombaroli et al., 2010). 445 However, there is a significant gap of archaeological settlements during the Bronze-Iron Age, 446 from 4000 cal yr BP onwards both in the Central (Fig. 4o; González-Sampériz et al., 2019) and 447 in the eastern Pyrenees (Gassiot Ballbè et al., 2014), despite an intensification of agricultural and grazing indicators has been detected in the eastern Pyrenean sequences (Miras et al., 2007; Pèlachs et al., 2007; Bal et al., 2011; Pérez-Obiol et al., 2012; Garcés-Pastor et al., 2017). This heterogeneous pattern in fire activity, during an arguable period of anthropogenic fire dynamics, could be associated with a steady but non-permanent human impact in mountain areas during the Bronze Age and onwards in a complex landscape scenario. Human-induced fires, would have locally maintained more open landscapes in specific areas (GonzálezSampériz et al., 2019).

A great spatial variability in terms of fire activity has also been observed in other European mountain ranges such as the Alps (Colombaroli et al., 2010; Leys et al., 2014) and in the

457 Carpathians (Feurdean et al., 2012; Florescu et al., 2018) but generally indicating increasing human related landscape transformations during the last 4000 years. to the intensification of the landscape opening over the last 1000 years, (increase in Artemisia, Poaceae, Cichorioideae, Chenopodiaceae) (Fig. $4 \mathrm{f}, \mathrm{m}$ ) as well as the high presence of human settlements in the eastern Pyrenees (Gassiot Ballbè, 2016). Simultaneously, and perhaps with a 
464 (MCA), a period of aridity recognized in most of south-western Europe (Seager et al., 2007; Moreno et al., 2012), could have also favoured fire occurrence.

In addition to this, historical documents record mining activities to exploit iron, silver and lead at least since Medieval times (Bielza de Ory et al., 1986) in the Bielsa-Parzán area (Fig. 1a) as well as in other Pyrenean areas (Pèlachs et al., 2009). The increase in herbs at this time, could be very likely related to the land-use intensification that occurred, as miners were given lands in order to ensure their permanence in the valley (Bielza de Ory et al., 1986). Both mining and smelting activities very likely affected forests through deforestation and burning due to increasing energy demand (Bielza de Ory et al., 1986; Jouffroy et al., 2005; Pèlachs et al., detected in MAR and BSM lakes at this time (Corella et al., 2018; Oliva-Urcia et al., 2018), probably related to the low intensity of the mining activities to cause a regional imprint.

MAR shows a prominent charcoal peak at the end of the $19^{\text {th }}$ century, which stays relatively high until ca. 1930 AD (Fig. 6). This tendency concurs with the Pb enrichment in MAR Lake sediments (Fig. 6) (Corella et al., 2018; Oliva-Urcia et al., 2018) likely related to the onset of large-scale $\mathrm{Pb}$ production in the Parzán area which started by the end of the $19^{\text {th }}$ century lasting until 1930, when the closure of the mines occurred due to the decrease in $\mathrm{Pb}$ prices (Nieto-Callén, 1996; Fanlo et al., 1998). The historical metal mining in this area ended at this time. This $\mathrm{Pb}$ enrichment is not detected in BSM, probably related to the lake characteristics and its lower altitude, that greatly reduce the lake sensitiveness to record historical pollution of trace metals as suggested by Corella et al. (2018). (being the maximum microcharcoal peak) (Fig. 4g) could be related to the large fires that 
where 2200 to $6500 \mathrm{Ha}$ of woodlands were burnt in each fire (El País, 1980; Vázquez de la Cueva, 2016).

490

5.3 How determinant was fire modifying alpine landscapes in the Pyrenees during the Holocene?

Regardless the site-to-site variations that seem to determine fire activity most, an interesting finding is that fire at these altitudes has not generally played a critical role in vegetation dynamics. This finding suggests that, as occurs in the present, past alpine and sub-alpine vegetation communities were not, broadly speaking, fire-prone neither fire-driven ecosystems (Leys et al., 2014). Thus, fire regimes may have not been the most relevant factor on forest dynamics, unlike Mediterranean ecosystems, which are composed of highly flammable sclerophilous vegetation (Keeley et al., 2012). This situation has also been observed in other studies in mountain areas e.g. in the Dolomites (Leys et al., 2014).

According to our data, the selected forest taxa in BSM and MAR are best characterised by their own endogenous effect, i.e., a higher antecedent presence of a particular taxa has a positive effect on its abundance (Fig. $5 a, c, d, e, f)$. In other words, a larger population will cope better with environmental change and disturbances, and remain large until a certain threshold in a specific forcing is reached. While in MAR fire may have played a more important role for potential source area, as several studies have evidenced that higher elevations may record best regional rather than local environmental variation (Escudero et al., 2016; Corella et al., 2018).

Fire at BSM might be indeed reflecting local but scattered events that, according to our data, 
512 pubescens or $Q$. humilis). This taxon, unlike all the others, may not have been locally present

513 nearby the lake (Pérez-Sanz et al., 2013). However, it successfully sprouts after fire generally

514 out-competing non-serotinous pines like the ones present in the sub-alpine belt (Sánchez-

515 Pinillos et al., 2018) as the ones present in BSM. MAR, more exposed to tropospheric

516 circulation due to its higher altitude, is possibly reflecting an even more regional picture of

517 both vegetation and fire variability. This fact implies, on the one hand, that proxies might be

518 recorded with larger lags than expected. On the other hand, it indicates that environmental

519 variability from different locations might be harmonized by sedimentary processes at these

520 altitudes that prevents evidencing spatial co-occurrent effects of disturbance on vegetation

521 response. Such might be the case of the positive effect that CHAR has on Abies if antecedent

522 PAR values are under the threshold (Fig. 5a). This would be one example of a, probable, lack of

523 spatial simultaneity on fire occurrence and vegetation response where charcoal and pollen

524 might be arriving from different areas. While this might be the case for all other taxa in MAR

525 too, concurrent CHAR is the only variable with a positive influence on Corylus PAR in this site

526 (Fig. 5b). In this particular case hazel is indeed a clear case of a temperate tree where both

527 neo- and palaeoecology studies (Tinner et al., 1999; Finsinger et al., 2006) have evidenced a

528 fast and positive fire response given its resprouting ability after burning (Delarze et al., 1992).

529 Besides the post-fire strategy, hazel pollen production is enhanced when vegetation is opened

530 by disturbance (Aaby, 1986; Bégeot, 1998). This fact is likely explaining why the concurrent

531 rather than the antecedent fire is more critical in affecting Corylus presence, as resprouting

532 and pollination would happen very soon after fire.

533 Finding that fire might not be the most critical factor shaping the long-term dynamics of the

534 analysed tree taxa has important consequences for conservation practices as fire occurrence

535 has been predominantly low in these sub-alpine areas and thus future scenarios with more

536 active fires might threaten the treeline ecosystems. In fact, the abandonment of agro-pastoral

537 activities in mountain areas during the past decades in the Pyrenees has provoked bush 
encroachment, which concurring with the rise in average temperatures, may increase fire risk during the next decades forced by the synergistic effect of both climate conditions and human impact

\section{Conclusion}

Here we present the comparison of two long-term fire activity records from different altitudes in the Central Pyrenees providing a better understanding of the Holocene fire-vegetation dynamics in this mountain range. Our results highlight that caution should be taken when comparing the results of different lacustrine sequences, even if they are in the same mountain range, and just few km away, as site-specific settings may determine different fire behaviour and source areas. We argue that fire activity during the early-to-mid-Holocene was relatively low and mostly controlled by climate. High summer temperatures together with high biomass accumulation led to a prolonged period of high fire activity during ca. $7000-6000 \mathrm{cal}$ yr BP as recorded in MAR with a coeval increase in fire activity, but shorter in duration, in BSM at ca. $6700 \mathrm{cal}$ yr BP. Burning decreased, concurring with the Neoglacial period, which suggests that climatic control was still dominant in promoting fire occurrence until 3700 cal yr BP, when fire activity increased coevally to the opening of the landscape and decoupled from climate as the only fire driver. Although from ca. 3000 cal yr BP onwards, fire activity decreases the increasing human pressure over the last centuries, lead to a remarkable rise in fire activity. Our results highlight that, overall fire activity does not seem to be a critical factor shaping alpine ecosystem through the Holocene. However, the increase in arboreal biomass due to abandonment of traditional land uses in mountain areas together with the rise in average temperatures during the last decades, may increase fire risk in the nearby future, as occurred in the HTM. 
564 Funding for this research was provided by the Spanish Inter-Ministry Commission of Science and Technology (CICYT) through the projects DINAMO3 (CGL2015-69160-R) and DINAMO2 (CGL-BOS2012-33063). Maria Leunda was supported by a PhD fellowship provided by the Spanish Ministry (FPI ref.: BES-2013-063753). Graciela Gil-Romera is funded by the DFG Research Unit FOR2358 "Mountain Exite Hypothesis". Blas M. Benito is supported by FRIMEDBIO (Research Council of Norway) through IGNEX (project 249894). We thank Elena Royo and Raquel López Cantero for the help provided during sediment sampling and Muriel Georget, Marie-Hélène Castera and Ludovic Devaux for laboratory assistance during microcharcoal preparation. We are in debt to Miguel-Sevilla-Callejo for the help provided in the design of Fig. 1.

\section{References}

575

Aaby, B., 1986. Trees as anthropogenic indicators in regional pollen diagrams from eastern Denmark. In: Geological survey of Denmark, A.A. Balkema (eds), Copenhagen. 73-93.

Alday, A., Montes, L., Baldellou, V., 2012. El Neolítico en la Cuenca del Ebro, in: El Neolítico En La Península Ibérica y Su Contexto Europeo. Ediciones Cátedra, Madrid, pp. 291-331.

Amatulli, G., Pérez-Cabello, F., de la Riva Fernández, 2007. Mapping lightning/human-caused wildfires occurrence under ignition point location uncertainty. Ecological Modelling 200, 321-333.

Araguas-Araguas, L.J., Díaz Teijeiro, M.F., 2005. Isotope composition of precipitation and water vapour in the Iberian Peninsula. In: Isotopic Composition of Precip-itation in the Mediterranean Basin in Relation to Air Circulation Patterns and Climate. International Atomic Energy Agency 173-190.

Archibald, S., Lehmann, C.E.R., Gómez-Dans, J.L., Bradstock, A., 2013. Defining pyromes and global syndromes of fire regimes. Proceedings of the National Academy of Sciences 110 (16), 6442-6447.

Bal, M., Albert, P., Ramon, P.-O., Julia, R., Raquel, C., 2011. Fire history and human activities during the last $3300 \mathrm{cal}$ yr BP in Spain's Central Pyrenees: The case of the Estany de Burg. Palaeogeography, Palaeoclimatology, Palaeoecology 179-190.

Baldellou, V., 1987. Avance al Estudio de la Espluga de la Puyascada. Bolskan 3-41.

Batalla, M., Ninyerola, M., Catalan, J., 2018. Digital long-term topoclimate surfaces of the Pyrenees mountain range for the period 1950-2012. Geoscience Data Journal 5, 50-62. https://doi.org/10.1002/gdj3.52

Bégeot, C., 1998. Le comportement pollinique du Noisetier (Corylus avellana), son rôle comme indicateur d'impacts anthropiques? L'exemple d'un transect dans le sud du Jura. Acta Botanica Gallica 145:4, 271-279. 
Bielza de Ory, V., Corral Lafuente, J.L., Escolano Urtilla, S., Laliena Corbera, C., Sesma Muñoz, A., Ubieto Arteta, A., 1986. Estudio Historiográfico del Valle de Bielsa (Huesca). Colección de Estudios Altoaragoneses. Huesca: Instituto de Estudios Altoaragoneses.

Birks, H.J.B., Björn, B., 2018. One hundred years of Quaternary pollen analysis 1916-2016. Vegetation History and Archaeobotany 27, 271-309. http://dx.doi.org/10.1007/s00334-017-0630-2

Blaauw, M., 2010. Methods and code for 'classical' age-modelling of radiocarbon sequences. Quaternary Geochronology 5, 512-518. https://doi.org/10.1016/j.quageo.2010.01.002

Blarquez, O., Carcaillet, C., 2010. Fire, fuel composition and resilience threshold in subalpine ecosystem. PLoS ONE 5 (8), e12480.

Bond, W.J., Midgley, J.J., 1995. Kill thy neighbour: an individualistic argument for the evolution of flammability. Oikos 73, 79-85.

Boulter, M.C., 1994. An approach to a standard terminology for palynodebris, in: Traverse, A. (Ed.), Sedimentation of Organic Particles. Cambridge University Press, Cambridge, pp. 199-216.

Bowman, D.M.J.S., Balch, J.K., Artaxo, P., Bond, W.J., Carlson, J.M., Cochrane, M.A., D'Antonio, C.M., DeFries, R.S., Doyle, J.C., Harrison, S.P., Johnston, F.H., Keeley, J.E., Krawchuk, M.A., Kull, C.A., Marston, J.B., Moritz, M.A., Prentice, I.C., Roos, C.I., Scott, A.C., Swetnam, T.W., van der Werf, G.R., Pyne, S.J., 2009. Fire in the Earth System. Science 324, 481-484.

Carracedo, V., Cunill, R., García-Codrón, J.C., Pèlachs, A., Pérez-Obiol, R., Soriano, J.M., 2017. History of fires and vegetation since the Neolithic in the Cantabrian Mountains (Spain). Land Degrad Dev.

Carrión, J.S., Fernández, S., González-Sampériz, P., Gil-Romera, G., Badal, E., Carrión-Marco, Y., López-Merino, L., López-Sáez, J.A., Fierro, E., Burjachs, F., 2010. Expected trends and surprises in the Lateglacial and Holocene vegetation history of the Iberian Peninsula and Balearic Islands. Review of Palaeobotany and Palynology, Iberian Floras through Time: Land of Diversity and Survival 162, 458-475. https://doi.org/10.1016/j.revpalbo.2009.12.007

Clark, J.S., 1988. Particle motion and the theory of charcoal analysis: source area, transport, deposition, and sampling. Quaternary Research 30, 67-80.

Clark, R.L., 1984. Effects on charcoal of pollen preparation procedures. Pollen et Spores 26, 559-576.

Clemente, I., Gassiot, E., Rey, J., Antolín, F., Obea, L., Viñerta, A., Saña-Seguí, M., 2016. Coro Trasito (Tella-Sin, HU) un asentamiento de pastores en el Pirineo Central con dataciones del neolítico antiguo y del Bronce medio, in: Lorenzo Lizalde, L. y Rodanés Vicente, J.M. (Eds.): Actas I Congreso de Arqueología y Patrimonio Aragonés, Zaragoza, Colegio Oficial de Doctores y Licenciados En Filosofía y Letras y Ciencias de Aragón. pp. 75-84.

Colombaroli, D., Henne, P.D., Kaltenrieder, P., Gobet, E., Tinner, W., 2010. Species responses to fire, climate and human impact at tree line in the Alps as evidenced by palaeoenvironmental records and a dynamic simulation model. Journal of Ecology 98, 13461357. https://doi.org/10.1111/j.1365-2745.2010.01723.x

Connor, S.E., Vanniere, B., Colombaroli, D., Anderson, R.S., Carrion, J., Ejarque, A., Gil-Romera, G., González-Sampériz, P., Hoefer, D., Morales-Molino, C., Revelles, J., Schneider, H., van der Knaap, W.O., van Leeuwen, J.F.N., Woodbridge, J., 2019. Humans take control of fire-driven diversity changes in Mediterranean Iberia's vegetation during the midlate Holocene. The Holocene 29 (5), 886-901.

Corella, J.P., Saiz-Lopez, A., Sierra, M.J., Mata, M.P., Millán, R., Morellón, M., Cuevas, C.A., Moreno, A., Valero-Garcés, B.L., 2018. Trace metal enrichment during the Industrial Period recorded across an altitudinal transect in the Southern Central Pyrenees. 
Science of The Total Environment 645, 761-772. https://doi.org/10.1016/j.scitotenv.2018.07.160

Cubo, M., Enríquez Alcalde, E., Gallar Pérez-Pastor, J.J., Jemes Díaz, V., López-García, M., Mateo Díez, M.L., Muñoz Correal, A., Parra Orgaz, P.J., 2012. los Incendios Forestales en España. Decenio 2001-2010, MAPAMA, Elsa Enríquez Alcalde y Laura Del Moral Vargaz (coord). ed. Madrid.

Cunill, R., Soriano, J.M., Bal, M.C., Pèlachs, A., Rodríguez, J.M., Pérez-Obiol, R., 2013. Holocene high-altitude vegetation dynamics in the Pyrenees: A pedoanthracology contribution to an interdisciplinary approach. Quaternary International 289, 60-70.

Daniau, A.-L., Bartlein, P.J., Harrison, S.P., Prentice, I.C., Brewer, S., Friedlingstein, P., HarrisonPrentice, T.I., Inoue, J., Izumi, K., Marlon, J.R., Mooney, S., Power, M.J., Stevenson, J., Tinner, W., Andrič, M., Atanassova, J., Behling, H., Black, M., Blarquez, O., Brown, K.J., Carcaillet, C., Colhoun, E.A., Colombaroli, D., Davis, B.A.S., D'Costa, D., Dodson, J., Dupont, L., Eshetu, Z., Gavin, D.G., Genries, A., Haberle, S., Hallett, D.J., Hope, G., Horn, S.P., Kassa, T.G., Katamura, F., Kennedy, L.M., Kershaw, P., Krivonogov, S., Long, C., Magri, D., Marinova, E., McKenzie, G.M., Moreno, P.I., Moss, P., Neumann, F.H., Norstrm, E., Paitre, C., Rius, D., Roberts, N., Robinson, G.S., Sasaki, N., Scott, L., Takahara, H., Terwilliger, V., Thevenon, F., Turner, R., Valsecchi, V.G., Vannière, B., Walsh, M., Williams, N., Zhang, Y., 2012. Predictability of biomass burning in response to climate changes. Global Biogeochemical Cycles 26, GB4007. https://doi.org/10.1029/2011GB004249

Daniau, A.-L., Sánchez-Goñi, M.F., Duprat, J., 2009. Last glacial fire regime variability in western France inferred from microcharcoal preserved in core MD04-2845, Bay of Biscay. Quaternary Research 71, 385-396.

Daniau, A.-L., Sánchez-Goñi, M.F., Martinez, P., Urrego, D.H., Bout-Roumazeilles, V., Desprat, S., Marlon, J.R., 2013. Orbital-scale climate forcing of grassland burning in southern Africa. PNAS 110 (13), 5069-5073.

Davis, P.T., Menounos, B., Osborn, G., 2009. Holocene and latest Pleistocene alpine glacier fluctuations: a global perspective. Quaternary Science Reviews, Holocene and Latest Pleistocene Alpine Glacier Fluctuations: A Global Perspective 28, 2021-2033. https://doi.org/10.1016/j.quascirev.2009.05.020

Delarze, R., Cladelari, D., Hainard, P., 1992. Effects of fire on forest dynamics in southern Switzerland. Journal of Vegetation Science 3, 55-60.

Ejarque, A., Miras, Y., Riera, S., Palet, J.M., Orengo, H.A., 2010. Testing micro-regional variability in the Holocene shaping of high mountain cultural landscapes: a palaeoenvironmental case-study in the eastern Pyrenees. Journal of Archaeological Science 37, 1468-1479. https://doi.org/10.1016/j.jas.2010.01.007

El País, E.E., 1980. La costa de Cataluña y los Pirineos, zonas más afectadas por los incendios. El País.

Escudero, M., Lozano, A., Hierro, J., Tapia, O., del Valle, J., Alastuey, A., Moreno, T., Anzano, J., Querol, X., 2016. Assessment of the variability of atmospheric pollution in National Parks of mainland Spain. Atmospheric Environment 132, 332-344.

Fanlo, I., Touray, J.C., Subías, I., Fernández-Nieto, C., 1998. Geochemical patterns of a sheared fluorite vein, Parzan, Spanish Central Pyrenees. Mineralium Deposita 33, 620-632.

Feurdean, A., Spessa, A., Magyari, E.K., Willis, K.J., Veres, D., Hickler, T., 2012. Trends in biomass burning in the Carpathian region over the last 15,000 years. Quaternary Science Reviews 45, 111-125. https://doi.org/10.1016/j.quascirev.2012.04.001

Feurdean, A., Veski, S., Florescu, G., Vanniere, B., Pfeiffer, M., O'Hara, R.B., Stivrins, N., Amon, L., Heinsalu, A., Vassiljev, J., Hickler, T., 2017. Broadleaf deciduous forest counterbalanced the direct effect of climate on Holocene fire regime in hemiboreal/boreal region (NE Europe). Quaternary Science Reviews 169, 378-390. 
Finsinger, W., Tinner, W., van der Knaap, W.O., Ammann, B., 2006. The expansion of hazel (Corylus avellana L.) in the southern Alps: a key for understanding its early Holocene history in Europe? Quaternary Science Reviews 25, 612-631. https://doi.org/10.1016/j.quascirev.2005.05.006

Florescu, G., Vanniere, B., Feurdean, A., 2018. Exploring the influence of local controls on fire activity using multiple charcoal records from northern Romanian Carpathians. Quaternary International 488, 41-57.

Font, I., 1983. Climatología de España y Portugal. Instituto Nacional de Meteorología. Madrid.

Fréjaville, T., Curt, C., Carcaillet, C., 2018. Higher potential fire intensity at the dry range margins of European mountain trees. Journal of Biogeography. https://doi.org/DOI: 10.1111/jbi.13386

Garcés-Pastor, S., Cañellas-Boltà, N., Pèlachs, A., Soriano, J.-M., Pérez-Obiol, R., Pérez-Haase, A., Calero, M.-A., Andreu, O., Escolà, N., Vegas-Vilarrúbia, T., 2017. Environmental history and vegetation dynamics in response to climate variations and human pressure during the Holocene in Bassa Nera, Central Pyrenees. Palaeogeography, Palaeoclimatology, Palaeoecology 479, 48-60. https://doi.org/10.1016/j.palaeo.2017.04.016

García-Ruiz, J.M., Lasanta, T., 2018. El Pirineo Aragonés como paisaje cultural. Pirineos 173, e038.

García-Ruiz, J.M., López-Moreno, J.I., Lasanta, T., Vicente-Serrano, S.M., González-Sampériz, P., Valero-Garcés, B.L., Sanjuán, Y., Beguería, S., Nadal-Romero, E., Lana-Renault, N., Gómez-Villar, A., 2015. Los efectos geoecológicos del cambio global en el Pirineo Central español: una revisión a distintas escalas espaciales y temporales. Pirineos 170, 012.

García-Ruiz, J.M., Palacios, D., de Andrés, N., Valero-Garcés, B.L., López-Moreno, J.I., Sanjuán, Y., 2014. Holocene and 'Little Ice Age' glacial activity in the Marboré Cirque, Monte Perdido Massif, Central Spanish Pyrenees. The Holocene 24, 1439-1452. https://doi.org/10.1177/0959683614544053

Gassiot Ballbè, E., 2016. Arqueología del pastoralismo en el Parque Nacional d'Aigüestortes i Estany de Sant Maurici: montañas humanizadas. Organismo Autónomo Parques Nacionales, Madrid.

Gassiot Ballbè, E., Rodríguez Antón, D., Pèlachs Mañosa, A., Pérez Obiol, R., Julià Brugués, R., Bal-Serin, M.-C., Mazzucco, N., 2014. La alta montaña durante la Prehistoria: 10 años de investigación en el Pirineo catalán occidental. Trabajos de Prehistoria 71, 261-281. https://doi.org/10.3989/tp.2014.12134

Gavin, D.G., Hu, F.S., Lertzman, K., Corbett, P., 2006. Weak climatic control of stand-scale fire history during the late Holocene. Ecology 87 (7), 1722-1732.

Gellatly, A.F., Grove, J.M., Switsur, V.R., 1992. Mid-Holocene glacial activity in the Pyrenees. The Holocene 2, 266-270. https://doi.org/10.1177/095968369200200309

Gil-Romera, G., González-Sampériz, P., Lasheras-Álvarez, L., Sevilla-Callejo, M., Moreno, A., Valero-Garcés, B., López-Merino, L., Carrión, J.S., Pérez Sanz, A., Aranbarri, J., GarcíaPrieto Fronce, E., 2014. Biomass-modulated fire dynamics during the Last GlacialInterglacial Transition at the Central Pyrenees (Spain). Palaeogeography, Palaeoclimatology, Palaeoecology 402, 113-124. https://doi.org/10.1016/j.palaeo.2014.03.015

Glantz, S.A., Slinker, B.K., Neilands, T.B., 2016. Primer of Applied Regression \& Analysis of Variance (Third ed.). McGraw Hill.

González-Sampériz, P., Aranbarri, J., Pérez-Sanz, A., Gil-Romera, G., Moreno, A., Leunda, M., Sevilla-Callejo, M., Corella, J.P., Morellón, M., Oliva, B., Valero-Garcés, B., 2017. Environmental and climate change in the southern Central Pyrenees since the Last Glacial Maximum: A view from the lake records. Catena 149, 668-688. https://doi.org/10.1016/j.catena.2016.07.041 
González-Sampériz, P., Montes, L., Aranbarri, J., Leunda, M., Domingo, R., Laborda, R., Sanjuan, Y., Gil-Romera, G., Lasanta, T., García-Ruiz, J.M., 2019. Escenarios, tempo e indicadores paleoambientales para la identificación del Antropoceno en el paisaje vegetal del Pirineo Central (NE Iberia). Cuadernos de Investigación Geográfica 45(1), 167-193.

González-Sampériz, P., Valero-Garcés, B.L., Moreno, A., Jalut, G., García-Ruiz, J.M., Martí-Bono, C., Delgado-Huertas, A., Navas, A., Otto, T., Dedoubat, J.J., 2006. Climate variability in the Spanish Pyrenees during the last 30,000 yr revealed by the El Portalet sequence. Quaternary Research 66, 38-52. https://doi.org/10.1016/j.yqres.2006.02.004

Habib, D., Eshet, Y., Van Pelt, R., 1994. Palynology of sedimentary cycles, in: Sedimentation of Organic Particles. Cambridge University Press, Cambridge, pp. 311-336.

Hart, G.F., Pasley, M.A., Gregory, W.A., 1994. Sequence stratigraphy and sedimentation of organic particles, in: Traverse, A. (Ed.), Sedimentation of Organic Particles. Cambridge University Press, Cambridge, pp. 337-390.

Hockaday, W.C., Grannas, A.M., Kim, S., Hatcher, P.G., 2006. Direct molecular evidence for the degradation and mobility of black carbon in soils from ultrahigh-resolution mass spectral analysis of dissolved organic matter from a fire-impacted forest soil. Organic Geochemistry 37, 501-510.

Hothorn, T., Hornik, K., Zeileis, A., 2006. Unbiased Recursive Partitioning: A Conditional Inference Framework. Journal of Computational and Graphical Statistcs 15(3), 651674.

Hothron, T., Zeileis, A., 2015. A Modular Toolkit for Recursive Partytioning in R. Journala of Machine Learning Research 16, 3905-3909.

IPPC, 2014. Climate Change 2014: Synthesis Report. Contribution of Working Groups I, II and III to the Fifth Assessment Report of the Intergovernmental Panel on Climate Change [Core Writing Team, R.K. Pachauri and L.A. Meyer (eds.)]. IPCC, Geneva, Switzerland, $151 \mathrm{pp}$.

Jiménez-Ruano, A., Rodrígues Mimbrero, M., Jolly, W.M., de la Riva Fernández, J., 2019. The role of short-term weather conditions in temporal dynamics of fire regime features in mainland Spain. Journal of Environmental Management 241, 575-586.

Johnstone, C.P., Lill, A., Reina, R.D., 2014. Habitat loss, fragmentationa nd degradation effects on small mammals: Alaysis with conditional inferece tree statistical modelling. Biological Conservation 176, 80-98.

Jones, T.P., Chaloner, W.G., Kuhlbusch, T.A.J., 1997. Proposed biogeological and chemical based terminology for fire-altered plant matter, in: Sediment Records of Biomass Burning and Global Change. NATO ASI Series. Clark, J.S., Cachier, H., Goldammer, J.G., Stocks, B. (Eds.). Springer, Berlin, Heidelberg, pp. 9-22.

Jouffroy, I., Pulido, M., Baron, S., Galop, D., Monna, F., Lavoie, M., Ploquim, A., Christophe, P., de Beaulieu, J.-L., Richard, H., 2005. Environmental impact of early paleometallurgy: pollen and geochemical analysis. Veget Hist Archaeobot 16, 251-258.

Keeley, J.E., Bond, W.J., Bradstock, R.A., Pausas, J.G., Rundel, P.W., 2012. Fire in Mediterranean Ecosystems. Ecology, Evolution and Management, Cambridge. ed.

Krawchuk, M.A., Moritz, M.A., 2011. Constraints on global fire activity vary across a resource gradient. Ecology 92 (1), 121-132.

Kumar, R., 2011. Neoglaciation, in: Encyclopedia of Snow, Ice and Glaciers. Springer, USA.

Laborda, R., Villalba-Mouco, V., Lanau, P., Gisbert, M., Sebastián, M., Domingo, R., Montes, L., 2017. El Puerto Bajo de Góriz (Parque Nacional de Ordesa y Monte Perdido). Ocupación y explotación de un paisaje de alta montaña desde la prehistoria hasta el siglo XX. Bolskan 26, 9-30.

Leunda, M., González-Sampériz, P., Gil-Romera, G., Aranbarri, J., Moreno, A., Oliva-Urcia, B., Sevilla-Callejo, M., Valero-Garcés, B., 2017. The Late-Glacial and Holocene Marboré Lake sequence (2612 m a.s.l., Central Pyrenees, Spain): Testing high altitude sites 
sensitivity to millennial scale vegetation and climate variability. Global and Planetary Change 157, 214-231. https://doi.org/10.1016/j.gloplacha.2017.08.008

Leunda, M., González-Sampériz, P., Gil-Romera, G., Bartolomé, M., Belmonte-Ribas, Á., GómezGarcía, D., Kaltenrieder, P., Rubiales, J.M., Schwörer, C., Tinner, W., Morales-Molino, C., Sancho, C., 2019. Ice cave reveals environmental forcing of long-term Pyrenean tree line dynamics. Journal of Ecology 107, 814-828. https://doi.org/10.1111/13652745.13077

Leverkus, A.R., García-Murillo, P., Jurado Doña, V., Pausas, J.G., 2019. Wildfires: Opportunity for restoration? Science 363 issue 6423.

Leys, B., Carcaillet, C., 2016. Subalpine fires: the roles of vegetation, climate and, ultimately, land uses. Clim. Change 135 (3-4), 683-697.

Leys, B., Carcaillet, C., Blarquez, O., Lami, A., Musazzi, S., Trevisan, R., 2014. Resistance of mixed subalpine forest to fire frequency changes: the ecological function of dwarf pine (Pinus mugo ssp. mugo). Quaternary Science Reviews 90, 60-68.

Marlon, J.R., Bartlein, P.J., Daniau, A.-L., Harrison, S.P., Maezumi, S.Y., Power, M.J., Tinner, W., Vanniére, B., 2013. Global biomass burning: a synthesis and review of Holocene paleofire records and their controls. Quaternary Science Reviews 65, 5-25. https://doi.org/10.1016/j.quascirev.2012.11.029

Minckley, T.A., Shriver, R.K., 2011. Vegetation Responses to Changing Fire Regimes in a Rocky Mountain Forest. Fire Ecology 7(2), 66-80.

Miras, Y., Ejarque, A., Riera, S., Palet, J.M., Orengo, H., Euba, I., 2007. Dynamique holocène de la végétation et occupation des Pyrénées andorranes depuis le Néolithique ancien, d'après l'analyse pollinique de la tourbière de Bosc dels Estanyons $(2180 \mathrm{~m}$, Vall del Madriu, Andorre). Comptes Rendus Palevol 6, 291-300. https://doi.org/10.1016/j.crpv.2007.02.005

Montes, L., Alday, A., 2012. Enredados en la malla neolítica de la cuenca del río Ebro. Redes, continuidades y cambios. Rubricatum 5, 51-60.

Montes, L., Domingo, R., González-Sampériz, P., Sebastián, M., Aranbarri, J., Castaños, P., García-Simón, L.M., Alcolea, M., Laborda, R., 2016. Landscape, resources and people during the Mesolithic and Neolithic times in NE Iberia: The Arba de Biel Basin. Quaternary International 403, 133-150. https://doi.org/10.1016/j.quaint.2015.05.041

Moore, P.D., Webb, J.A., Collison, M.E., 1991. Pollen Analysis, 2nd Ed. ed.

Morales-Molino, C., Colombaroli, D., Valbuena, M., Tinner, W., Salomón, R., Carrión, J., Gil, L., 2017. Land-use history as a major driver for long-term forest dynamics during the last millennia in the Sierra de Guadarrama National Park (central Spain) and implications for forest conservation and management. Global and Planetary Change 152, 64-75. https://doi.org/10.1016/j.gloplacha.2017.02.012

Moreno, A., Pérez, A., Frigola, J., Nieto-Moreno, V., Rodrigo-Gámiz, M., Martrat, B., GonzálezSampériz, P., Morellón, M., Martín-Puertas, C., Corella, J.P., Belmonte, Á., Sancho, C., Cacho, I., Herrera, G., Canals, M., Grimalt, J.O., Jiménez-Espejo, F., Martínez-Ruiz, F., Vegas-Vilarrúbia, T., Valero-Garcés, B.L., 2012. The Medieval Climate Anomaly in the Iberian Peninsula reconstructed from marine and lake records. Quaternary Science Reviews 43, 16-32. https://doi.org/10.1016/j.quascirev.2012.04.007

Nieto-Callén, J.J., 1996. El proceso sidero-metalúrgico altoaragonés: los valles de Bielsa y Gistaín en la edad moderna (1565-1800)., in: Lull. Vol 19, N37.

Ninyerola, M., Pons, X., Roure, J.M., 2005. Atlas Climático Digital de la Península Ibérica. Metodología y Aplicaciones en Bioclimatología y Geobotánica ISBN 932860-8-7 Universidad Autónoma de Barcelona, Bellaterra Data available at http://opengis.uab. es/wms/iberia/.

Ogle, K., Barber, J.J., Barron-Gafford, G.A., Bentley, L.P., Young, J.M., Huxman, T.E., Loik, M.E., Tissue, D.T., 2015. Quantifying ecological memory in plant and ecosystem processes. Ecology Letters 18, 221-235. https://doi.org/10.1111/ele.12399 
Oliva-Urcia, B., Moreno, A., Leunda, M., Valero-Garcés, B., González-Sampériz, P., Gil-Romera, G., Mata, M.P., Group, H., 2018. Last deglaciation and Holocene environmental change at high altitude in the Pyrenees: the geochemical and paleomagnetic record from Marboré Lake (N Spain). J Paleolimnol 59, 349-371. https://doi.org/10.1007/s10933017-0013-9

Ona and Calastrenc, 2009. Historia de de los Hospitales de Benasque y Bañeras de Luchón Ocho siglos de hospitalidad al pie del Aneto. Fundación Hospital de Benasque.

Padisak, J., 1992. Seasonal auccession of phytoplankton in a large shallow lake (Balaton, Hungary) - a dynamic approach to ecological ., its possible role and mechanisms. Journal of Ecology 80, 217-230.

Pauli, H., Gottfried, M., Dullinger, S., Abdaladze, O., Akhalkatsi, M., Alonso, J.L.B., Coldea, G., Dick, J., Erschbamer, B., Calzado, R.F., Ghosn, D., Holten, J.I., Kanka, R., Kazakis, G., Kollár, J., Larsson, P., Moiseev, P., Moiseev, D., Molau, U., Mesa, J.M., Nagy, L., Pelino, G., Puşcaş, M., Rossi, G., Stanisci, A., Syverhuset, A.O., Theurillat, J.-P., Tomaselli, M., Unterluggauer, P., Villar, L., Vittoz, P., Grabherr, G., 2012. Recent Plant Diversity Changes on Europe's Mountain Summits. Science 336, 353-355. https://doi.org/10.1126/science.1219033

Pausas, J.G., Keeley, J.E., 2014. Abrupt climate-independent fire regime changes 17 (6), 11091120.

Pausas, J.G., Schwilk, D.W., 2012. Fire and plant evolution. New Phytologist 193, 301-303.

Pèlachs, A., Nadal, J., Soriano, J.M., Molina, D., Cunill, R., 2009. Changes in Pyrenean woodlands as a result of the intensity of human exploitation: 2,000 years of metallurgy in Vallferrera, northeast Iberian Peninsula. Vegetation History and Archaeobotany 18, 403-416. https://doi.org/10.1007/s00334-009-0218-6

Pèlachs, A., Soriano, J.M., Nadal, J., Esteban Amat, A., 2007. Holocene environmental history and human impact in the Pyrenees. Contributions to science 421-429.

Pérez-Obiol, R., Bal, M.-C., Pèlachs, A., Cunill, R., Soriano, J.M., 2012. Vegetation dynamics and anthropogenically forced changes in the Estanilles peat bog (southern Pyrenees) during the last seven millennia. Veget Hist Archaeobot 21, 385-396. https://doi.org/10.1007/s00334-012-0351-5

Pérez-Sanz, A., González-Sampériz, P., Moreno, A., Valero-Garcés, B., Gil-Romera, G., Rieradevall, M., Tarrats, P., Lasheras-Álvarez, L., Morellón, M., Belmonte, A., Sancho, C., Sevilla-Callejo, M., Navas, A., 2013. Holocene climate variability, vegetation dynamics and fire regime in the central Pyrenees: the Basa de la Mora sequence (NE Spain). Quaternary Science Reviews 73, 149-169. https://doi.org/10.1016/j.quascirev.2013.05.010

Power, M.J., Marlon, J., Ortiz, N., Bartlein, P.J., Harrison, S.P., Mayle, F.E., Ballouche, A., Bradshaw, R.H.W., Carcaillet, C., Cordova, C., Mooney, S., Moreno, P.I., Prentice, I.C., Thonicke, K., Tinner, W., Whitlock, C., Zhang, Y., Zhao, Y., Ali, A.A., Anderson, R.S., Beer, R., Behling, H., Briles, C., Brown, K.J., Brunelle, A., Bush, M., Camill, P., Chu, G.Q., Clark, J., Colombaroli, D., Connor, S., Daniau, A.-L., Daniels, M., Dodson, J., Doughty, E., Edwards, M.E., Finsinger, W., Foster, D., Frechette, J., Gaillard, M.-J., Gavin, D.G., Gobet, E., Haberle, S., Hallett, D.J., Higuera, P., Hope, G., Horn, S., Inoue, J., Kaltenrieder, P., Kennedy, L., Kong, Z.C., Larsen, C., Long, C.J., Lynch, J., Lynch, E.A., McGlone, M., Meeks, S., Mensing, S., Meyer, G., Minckley, T., Mohr, J., Nelson, D.M., New, J., Newnham, R., Noti, R., Oswald, W., Pierce, J., Richard, P.J.H., Rowe, C., Sanchez Goñi, M.F., Shuman, B.N., Takahara, H., Toney, J., Turney, C., Urrego-Sanchez, D.H., Umbanhowar, C., Vandergoes, M., Vanniere, B., Vescovi, E., Walsh, M., Wang, X., Williams, N., Wilmshurst, J., Zhang, J.H., 2008. Changes in fire regimes since the Last Glacial Maximum: an assessment based on a global synthesis and analysis of charcoal data. Clim Dyn 30, 887-907. https://doi.org/10.1007/s00382-007-0334-x 
Quénéa, K., Derenne, S., Rumpel, C., Rouzaud, J.N., Gustafsson, O., Carcaillet, C., Mariotti, A., Largeau, C., 2006. Black carbon yields and types in forest and cultivated sandy soils (Landes de Gascogne, France) as determined with different methods: Influence of change in land use. Organic Geochemistry 37, 1185-1189.

Reille, M., 1992. Pollen et Spores d'Europe et d'Afrique du Nord. Marseille.

Remy, C., Fouquemberg, C., Asselin, H., Andrieux, B., Magnan, G., Brossier, B., Grondin, P., Bergeron, Y., Talon, B., Girardin, M.P., Blarquez, O., Bajolle, L., Ali, A.A., 2018. Guidelines for the use and interpretation of palaeofire reconstructionsbased on various archives and proxies. Quaternary Science Reviews 193, 312-322.

Renssen, H., Seppä, H., Heiri, O., Roche, D.M., Goosse, H., Fichefet, T., 2009. The spatial and temporal complexity of the Holocene thermal maximum. Nature Geoscience 2, 411414. https://doi.org/10.1038/ngeo513

Rius, D., Vannière, B., Galop, D., Richard, H., 2011. Holocene fire regime changes from multiple-site sedimentary charcoal analyses in the Lourdes basin (Pyrenees, France). Quaternary Science Reviews 30, 1696-1709.

Rojo, M., Peña, L., Royo, J.I., Tejedor, C., García, I., Arcusa, H., Garrido, R., Moreno, M., Mazzuco, N., Gibaja, J.F., Ortega, D., Kromer, B., Alt, K., 2013. Pastores trashumantes del Neolítico antiguo en un entorno de alta montana: secuencia crono-cultural de la Cova de Els Trocs (San Feliú de Veri, Huesca). Boletín del Seminario de Arte y Arqueología 79, 9-55.

Rojo-Guerra, M., García-Martínez de Lagrán, I., González-Sampériz, P., 2018. El Pirineo central y occidental en los inicios del Neolítico, in: Monografies Del MAC 2, Barcelona. pp. 1735.

Ryan, K.C., 2000. Wildland fire in ecosystems: effects of fire on flora. In Brown, J.K., Kapler Smith J. (Eds.), Global Change and Widland Fire. U.S. Department of Agriculture, Forest Service, Rocky Mountain Research Station, pp. 175-183.

Samartin, S., Heiri, O., Joos, F., Renssen, H., Franke, J., Brönnimann, S., Tinner, W., 2017. Warm Mediterranean mid-Holocene summers inferred from fossil midge assemblages. Nature Geosci 10, 207-212. https://doi.org/10.1038/ngeo2891

Sánchez-Pinillos, M., Ameztegui, A., Kitzberger, T., Coll, L.-, 2018. Relative size to resprouters determines post-fire recruitment of non serotinous pines. Forest Ecology and Management 429, 300-307.

Schwörer, C., Colombaroli, D., Kaltenrieder, P., Rey, F., Tinner, W., 2015. Early human impact (5000-3000 BC) affects mountain forest dynamics in the Alps. J Ecol 103, 281-295. https://doi.org/10.1111/1365-2745.12354

Seager, R., Graham, N., Herweijer, C., Arnold, L.G., Kushnir, Y., Cook, Ed., 2007. Blueprints for Medieval hydroclimate. Quat Sci Rev 26 (19-20), 2322-2336.

Stevens-Rumann, C.S., Kemp, K.B., Higuera, P.E., Harvey, B.J., Rother, M.T., Donato, D.C., Morgan, P., Veblen, T.T., 2018. Evidence for declining forest resilience to wildfires under climate change. Ecology Letters 21, 243-252. https://doi.org/10.1111/ele.12889

Stockmarr, J., 1971. Tablets with spores used in absolute pollen analysis. Pollen Spores 13, 614-621.

Tarrats, P., Heiri, O., Valero-Garces, B., Cañedo-Argüelles, M., Prat, N., Rieradevall, M., González-Sampériz, P., 2018. Chironomid-inferred Holocene Temperature Reconstruction in Basa de la Mora Lake (Central Pyrenees). The Holocene 28 (11), 1685-1696.

Theurillat, J.-P., Guisan, A., 2001. Potential Impact of Climate Change on Vegetation in the European Alps: A Review. Climatic Change 50, 77-109. https://doi.org/10.1023/A:1010632015572

Tinner, W., Beer, R., Bigler, C., Clegg, B.F., Jones, R.T., Kaltenrieder, P., van Raden, U.J., Gilli, A., $\mathrm{Hu}$, F.S., 2015. Late-Holocene climate variability and ecosystem responses in Alaska inferred from high-resolution multiproxy sediment analyses at Grizzly Lake. 
$\begin{array}{llll}\text { Quaternary } & \text { Science } & \text { Reviews } & 126,\end{array}$ https://doi.org/10.1016/j.quascirev.2015.08.019

Tinner, W., Conedera, M., Ammann, B., W. Gaggeler, Heinz.W., Gedye, S., Jones, R., Sagesser, B., 1998. Pollen and charcoal in lake sediments compared with historically documented forest fires in southern Switzerland since AD 1920. The Holocene 8, 3142.

Tinner, W., Conedera, M., Brigitta, A., Lotter, A.F., 2005. Fire ecology north and south of the Alps since the last ice age. The Holocene 15 (8), 1214-1226.

Tinner, W., Hubschmid, P., Wehrli, M., Ammann, B., Conedera, M., 1999. Long-term forest fire ecology and dynamics in southern Switzerland. Journal of Ecology 87, 273-289. https://doi.org/10.1046/j.1365-2745.1999.00346.x

Valdeyron, N., Bosc-Zanardo, Br., Briand, Th., 2008. The evolution of stone weapon elements and cultural dynamics during the Mesolithic in Southwestern France: the case of the Haut Quercy (Lot, France), in Pétillon J.-M., Dias-Meirinho M.-H., Cattelain P., Honegger M., Normand Chr., Valdeyron N. (eds.), Projectile weapon elements from the Upper Palaeolithic to the Neolithic, Proceedings of session C83, XVth world congress UISPP, Lisbonne, 2006, P@lethnologie, 1, 269-286.

Vannière, B., Blarquez, O., Rius, D., Doyen, E., Brücher, T., Colombaroli, D., Connor, S., Feurdean, A., Hickler, T., Kaltenrieder, P., Lemmen, C., Leys, B., Massa, C., Olofsson, J., 2016. 7000-year human legacy of elevation-dependent European fire regimes. Quaternary Science Reviews 132, 206-212. https://doi.org/10.1016/j.quascirev.2015.11.012

Vannière, B., Power, M.J., Roberts, N., Tinner, W., Carrion, J., Magny, M., Bartlein, P., Colombaroli, D., Daniau, A.L., Finsinger, W., Gil-Romera, G., Kaltenrieder, P., Pini, R., Sadori, L., Turner, R., Valsecchi, V., Vescovi, E., 2011. Circum-Mediterranean fire activity and climate changes during the mid-Holocene environmental transition (85002500 cal. BP). The Holocene 21, 53-73. https://doi.org/10.1177/0959683610384164

Vázquez de la Cueva, A., 2016. Incendios forestales en la España peninsular (1974-2010). Análisis temporal y espacial desde una perspectiva ecológica. Manuscrito del autor publicado como Monografía INIA, Serie Forestal ${ }^{\circ} 29$.

Verardo, J., 1997. Charcoal analysis in marine sediments. Limnology Oceanography 42, 192197.

Villar, L., Sesé, J.A., Ferrández, J.V., 1997. Atlas Flora del Plrineo Aragonés, Consejo de Protección de la Naturaleza de Aragón. Instituto de Estudios Altoaragoneses. ed.

Walker, M.J.C., Berkelhammer, M., Björck, S., Cwynar, L.C., Fisher, D.A., Long, A.J., Lowe, J.J., Newnham, R.M., Rasmussen, S.O.,Weiss, H., 2012. Formal subdivision of the Holocene series/epoch: a discussion paper by a working group of INTIMATE (integration of icecore, marine and terrestrial records) and the subcommission on Quaternary stratigraphy (International Commission on Stratigraphy). J. Quat. Sci. 27, 649-659.

Wastl, C., Schunk, C., Lüpke, M., Cocca, G., Conedera, M., Valese, E., Menzel, A., 2013. Largescale weather types, forest fire danger, and wildfire occurrence in the Alps 168, 15-25.

Whitlock, C., Higuera, P.E., McWethy, D.B., Briles, C.E., 2010. Paleoecological perspectives on fire ecology: revisiting the fire-regime concept. The Open Ecology Journal 3, 6-23.

Whitlock, C., Larsen, C., 2001. Charcoal as a fire proxy, in: Tracking Environmental Change Using Lake Sediments. Terrestrial, Algal, and Siliceous Indicators. Kluwer, Dordrecht, pp. 75-97. 
1007 The code and data are available in this GitHub link: https://github.com/BlasBenito/PyreFire,

1008 and are deposited in Zenodo under the DOI 10.5281/zenodo.3266002.

1009

1010

1011 Figures

1012

1013 Holocene fire and vegetation dynamics in the Central

1014 Pyrenees (Spain)

1015

1016 Maria Leunda, Graciela Gil-Romera, Anne-Laure

1017 Daniau, Blas M. Benito, Penélope González-Sampériz 

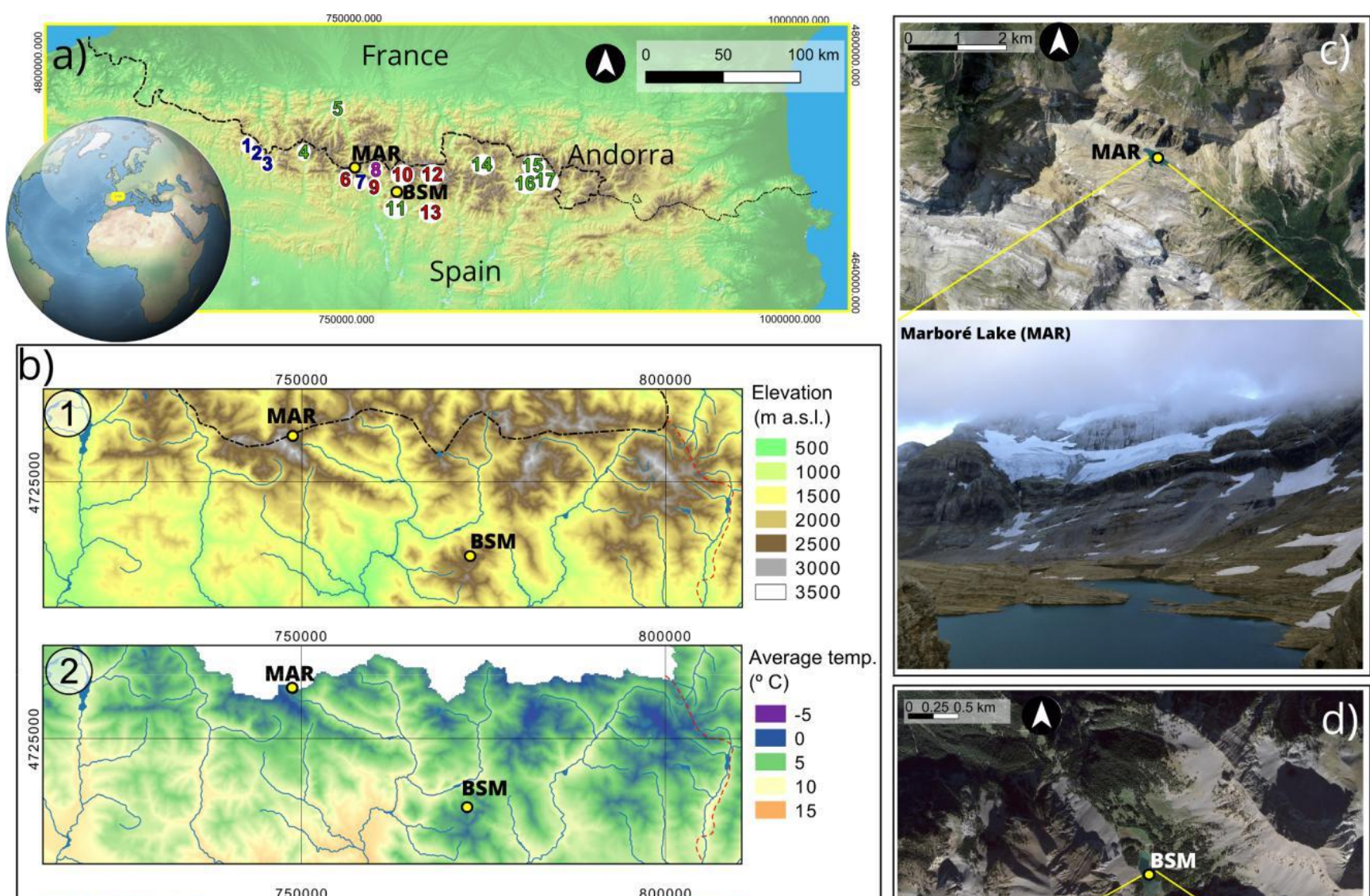

Average temp

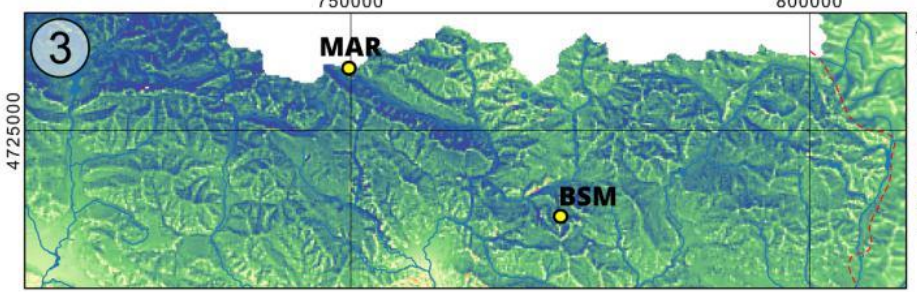

Annual precip.

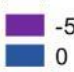

-5
0
-
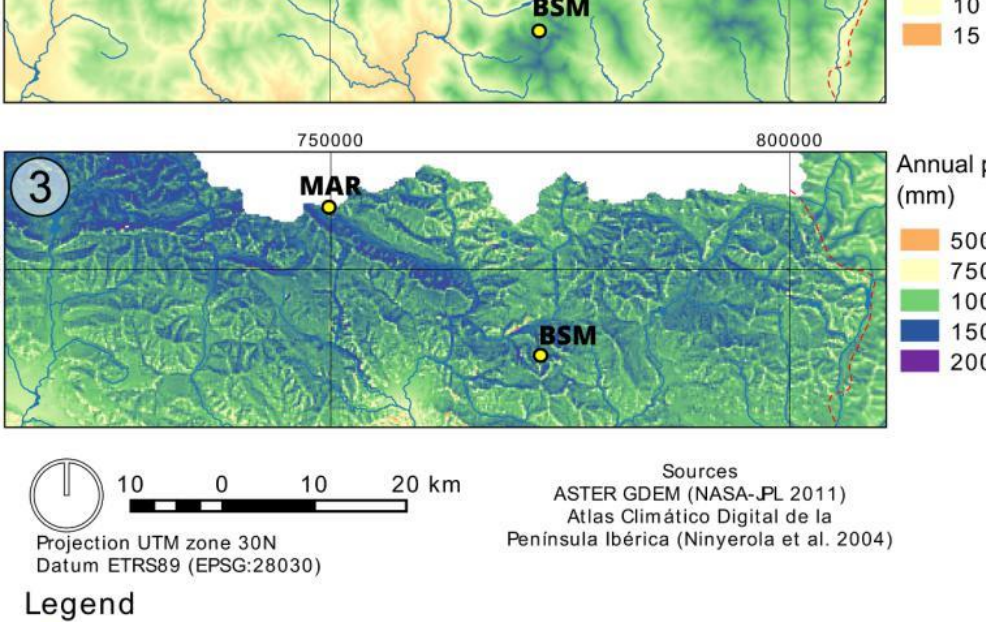

ASTER GDEM (NASA-PL 2011)

Atlas Climático Digital de la Peninsula Ibérica (Ninyerola et al. 2004)

\section{Legend}

$\begin{array}{ll}\text { O Study sites } & \text { rivers } \\ \text { Other palaeoenvironmental sequences } & \text {--.- international boundary } \\ \text { Archaeological settlements } & --- \text { regional boundary } \\ \text { Palaeofire levels } & \text { Mires }\end{array}$

1019 Figure 1. (a) Location map of the study lakes Marboré (MAR) and Basa da la Mora

1020 (BSM) in the Pyrenees together with other existing records; in blue: dated palaeofire

1022 levels; in red: archaeological settlements; in green: other existing fire and pollen

1023 records; in pink: mires. 1: Plandaniz (González-Sampériz et al., 2019); 2: Aragüés

1024 (González-Sampériz et al., 2019); 3: Las Blancas (González-Sampériz et al., 2019), 4:

1025 Portalet peatbog (González-Sampériz et al., 2006; Gil-Romera et al., 2014); 5: Lourdes 
Lake (Rius et al., 2011); 6: Barranco Pardina (Laborda et al., 2017); 7: Valle Pardina

1027 (González-Sampériz et al., 2019); 8: Parzán mires; 9: Corotrasito (Clemente et al.,

1028

1029

1030

1031

1032

1033

1034

1035

1036

1037

1038

2016); 10: Puyascada (Baldellou, 1987); 11: Armeña-A294 Ice Cave (Leunda et al.,

2019); 12: Hospital de Benasque (Ona and Calastrenc, 2009); 13: Els Trocs (Rojo et al.,

2013); 14: Bassa Nera (Garcés-Pastor et al., 2017); 15: Estanilles peatbog (Pérez-Obiol

et al., 2012); 16: Plaus de Bodis-Montarenyo (Cunill et al., 2013); 17: Burg (Pèlachs et

al., 2011). (b) Topographic (1), Temperature (2) and Precipitation (3) maps of the study

areas. c) Ortophoto and photography of the MAR Lake and surrounding area. d)

Ortophoto and photography of BSM and surrounding area (Google, Imagery 2019.

CNES. Institut Cartografic de Catalunya, Landsat. Copernicus, Maxar Technologies,

Map data 2019).

1039

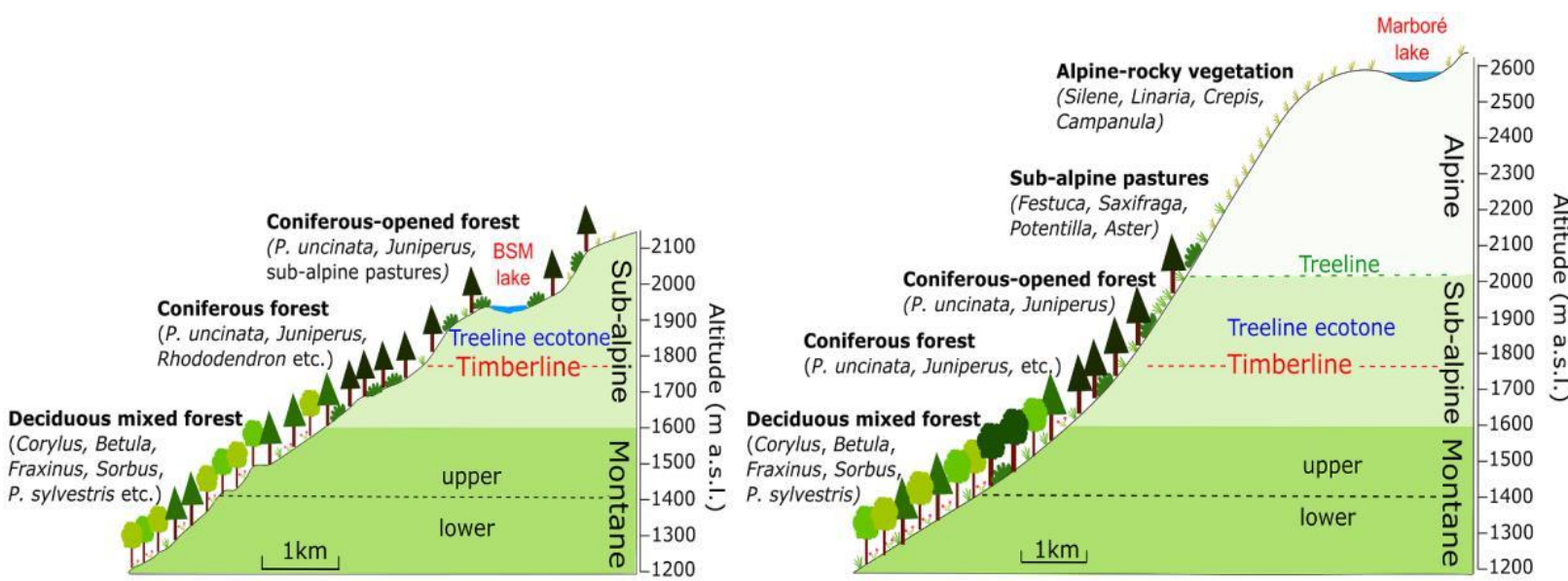

1040

Figure 2. Simplified vegetation transects for Basa de la Mora (left) and Marboré (right)

1041

sites. 
Table 1

1049 Summary of main features of Marboré and Basa de la Mora Lakes. MAP: mean annual precipitation; SP: summer precipitation; WP: winter precipitation; MAT: mean annual temperature; SMMT: summer mean maximum temperature. Climatic data have been extracted from Ninyerola et al. (2005) and Batalla et al. (2018).

\begin{tabular}{|c|c|c|}
\hline & Basa de la Mora (BSM) & Marboré (MAR) \\
\hline Coordinates & $42^{\circ} 32^{\prime} \mathrm{N}, 0^{\circ} 19^{\prime} \mathrm{E}$ & $42^{\circ} 41^{\prime} \mathrm{N}, 0^{\circ} 2^{\prime} \mathrm{E}$ \\
\hline Altitude (m a. s. l.) & 1914 & 2612 \\
\hline \multirow[t]{3}{*}{ Lake type and dimensions } & . Holomictic lake & . Cold Dimictic lake \\
\hline & $\cdot \sim 300 \mathrm{~m}$ length & $\cdot \sim 500 \mathrm{~m}$ length \\
\hline & . $\sim 100 \mathrm{~m}$ across & . 200 $\mathrm{m}$ across \\
\hline \multirow{5}{*}{ Lake basin characteristics } & - Maximum water depth of $4.5 \mathrm{~m}$ & - Maximum water depth of $30 \mathrm{~m}$ \\
\hline & - Shallow glacial lake & - Alpine glacial lake \\
\hline & $\begin{array}{l}\text { Glacial over-deepened basin enclosed } \\
\text { by a frontal }\end{array}$ & $\begin{array}{l}\text {-Glacial over-deepened basin within a } \\
\text { glacial cirque at the border }\end{array}$ \\
\hline & $\begin{array}{l}\text { moraine, surrounded by steep limestone } \\
\text { walls }\end{array}$ & $\begin{array}{l}\text { between the northern and the southern } \\
\text { slopes of the Pyrenees }\end{array}$ \\
\hline & $\begin{array}{l}\text { Catchment consists of Mesozoic } \\
\text { limestones and sandy }\end{array}$ & $\begin{array}{l}\text { Sandy limestones and fine-grain sandstones } \\
\text { cemented by a carbonatic }\end{array}$ \\
\hline \multirow[b]{2}{*}{ MAP } & limestones & matrix \\
\hline & $1500 \mathrm{~mm}$ & $2000 \mathrm{~mm}$ \\
\hline
\end{tabular}




\begin{tabular}{|c|c|c|}
\hline SP & ca. $180 \mathrm{~mm}$ & ca. $230 \mathrm{~mm}$ \\
\hline WP & ca. $150 \mathrm{~mm}$ & ca. $200 \mathrm{~mm}$ \\
\hline MAT & $5^{\circ} \mathrm{C}$ & $0^{\circ} \mathrm{C}$ \\
\hline SMMT & $15^{\circ} \mathrm{C}$ & $10^{\circ} \mathrm{C}$ \\
\hline Vegetation belt & Sub-alpine & Alpine \\
\hline $\begin{array}{l}\text { Treeline altitude } \\
\text { valley (m a.s.l.) }\end{array}$ & $2000-2200$ & $2000-2100$ \\
\hline $\begin{array}{l}\text { Timberline altitu } \\
\text { valley }(\mathrm{m}\end{array}$ & $1700-1900$ & $1700-1900$ \\
\hline $\begin{array}{c}\text { a.s.l.) } \\
\text { Local vegetation }\end{array}$ & $\begin{array}{l}\text { Treeline ecotone: } P \text {. uncinata together } \\
\text { with } J . \text { communis, }\end{array}$ & $\begin{array}{l}\text { Patches of annual and perennial herbs such } \\
\text { as Silene acaulis, Linaria }\end{array}$ \\
\hline & R. ferrugineum and sub-alpine pastures & alpina and Crepis pygmaea \\
\hline
\end{tabular}

Basa de la Mora

1057

1058

1059

1060

1061

1062

1063

1064

1065
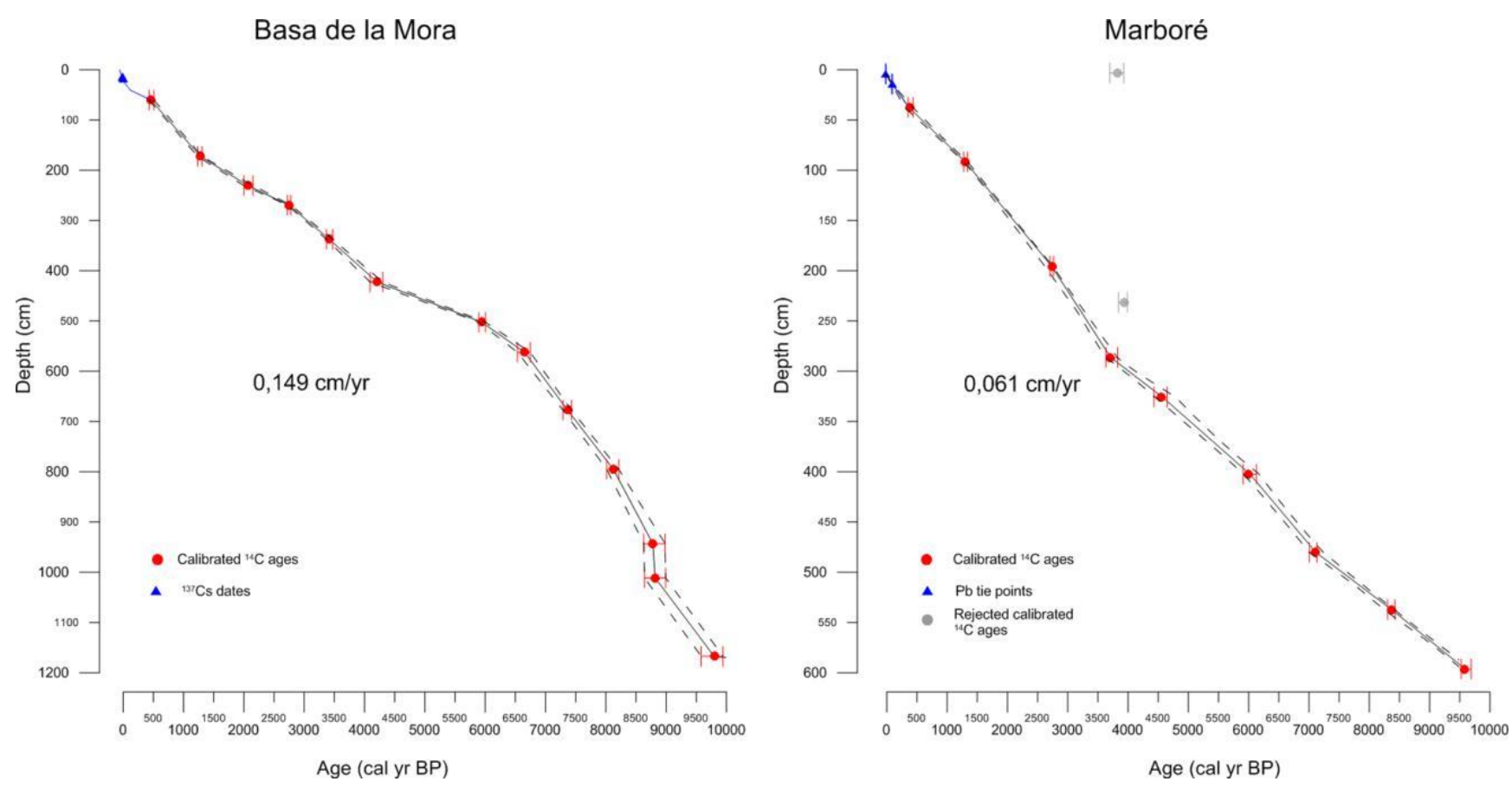
1066 Figure 3. Holocene depth-age models for both sequences based on Pérez-Sanz et al.

1067 (2013) and Leunda et al. (2017).

1068

1069 
Age (cal yr BP)

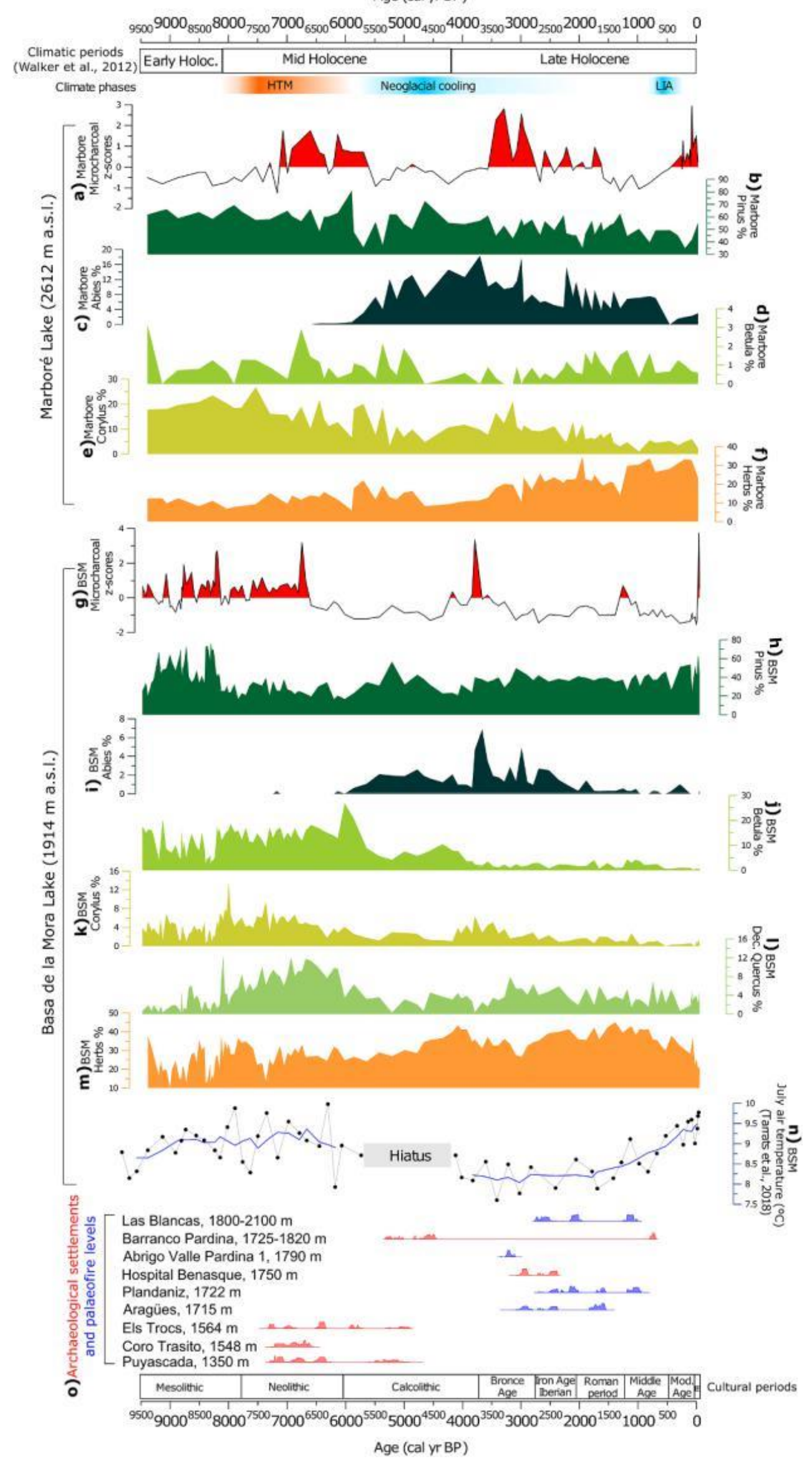


1071 Figure 4. Comparison of different indicators from both MAR and BSM lake se1072 quences: (a) and (g) Microcharcoal z-scores from MAR and BSM sequences (the red 1073 shade indicate values above 0 in the z-scores standardized values), selected pollen taxa 1074 from MAR: (b) Pinus, (c) Abies, (d) Betula, (e) Corylus, and (f) Herbs (Leunda et al., 1075 2017), selected pollen taxa from BSM: (h) Pinus, (i) Abies, (j) Betula, (k) Corylus, (l) 1076 Deciduous Quercus and (m) Herbs (Pérez-Sanz et al., 2013), (n) Chironomid-based 1077 Holocene summer temperature reconstruction from BSM (Tarrats et al., 2018) and (o) 1078 distribution and probability sum of calibrated radiocarbon dates of archaeological 1079 settlements (in red) and pa-laeofire layers, referring to layers in a soil, paleosoil, 1080 stratified scree or ravine which contain abundant charcoal particles of past fires (in blue) 1081 in the Central Pyrenees. Palaeofires: Las Blancas, Abrigo Valle Pardina; Plandániz, 1082 Aragüés (González-Sampériz et al., 2019). Archaeological settlements: Hospital de Be1083 nasque (Ona and Calastrenc, 2009), Barranco Pardina (Laborda et al., 2017), Coro 1084 Trasito (Clemente et al., 2016), Puyascada (Baldellou, 1987) Els Trocs (Rojo et al., 1085 2013). HTM: Holocene Thermal Maximum. LIA: Little Ice Age. (See above-mentioned 1086 references for further information.) 

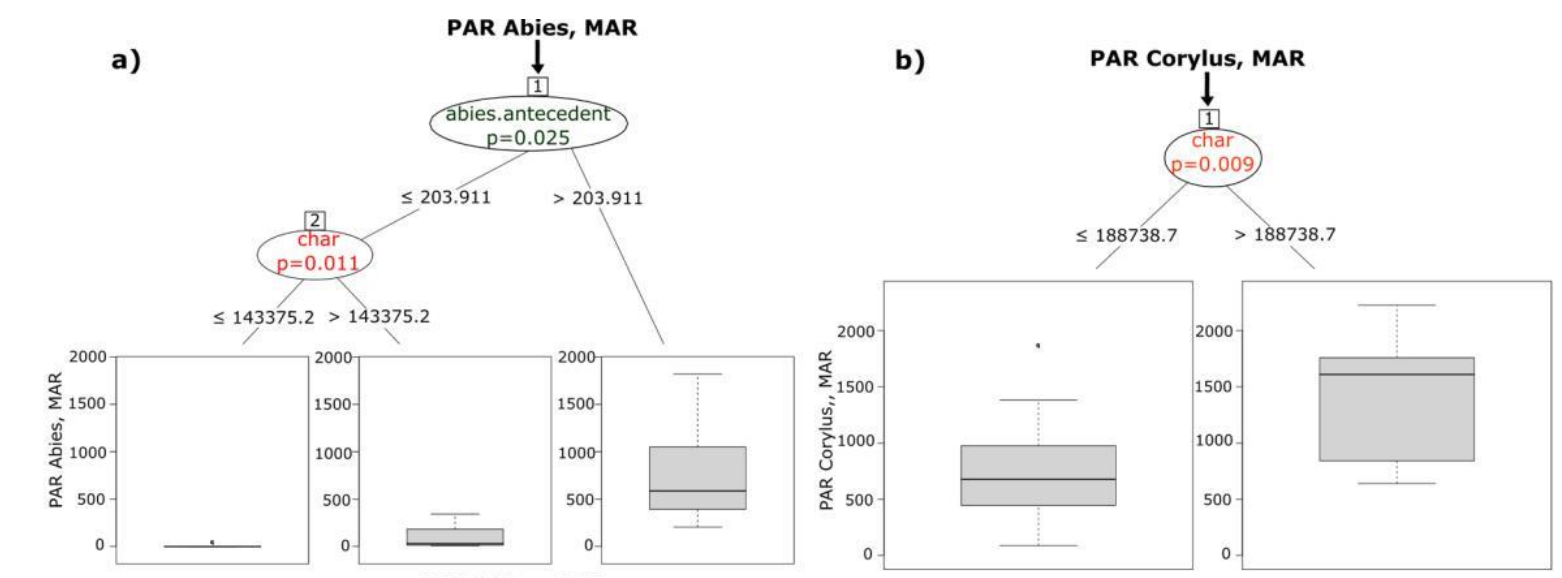

c)

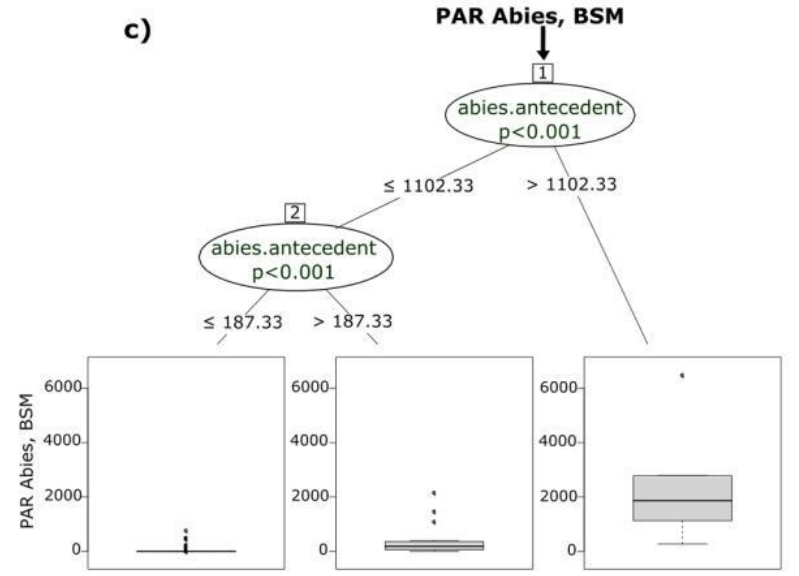

e)
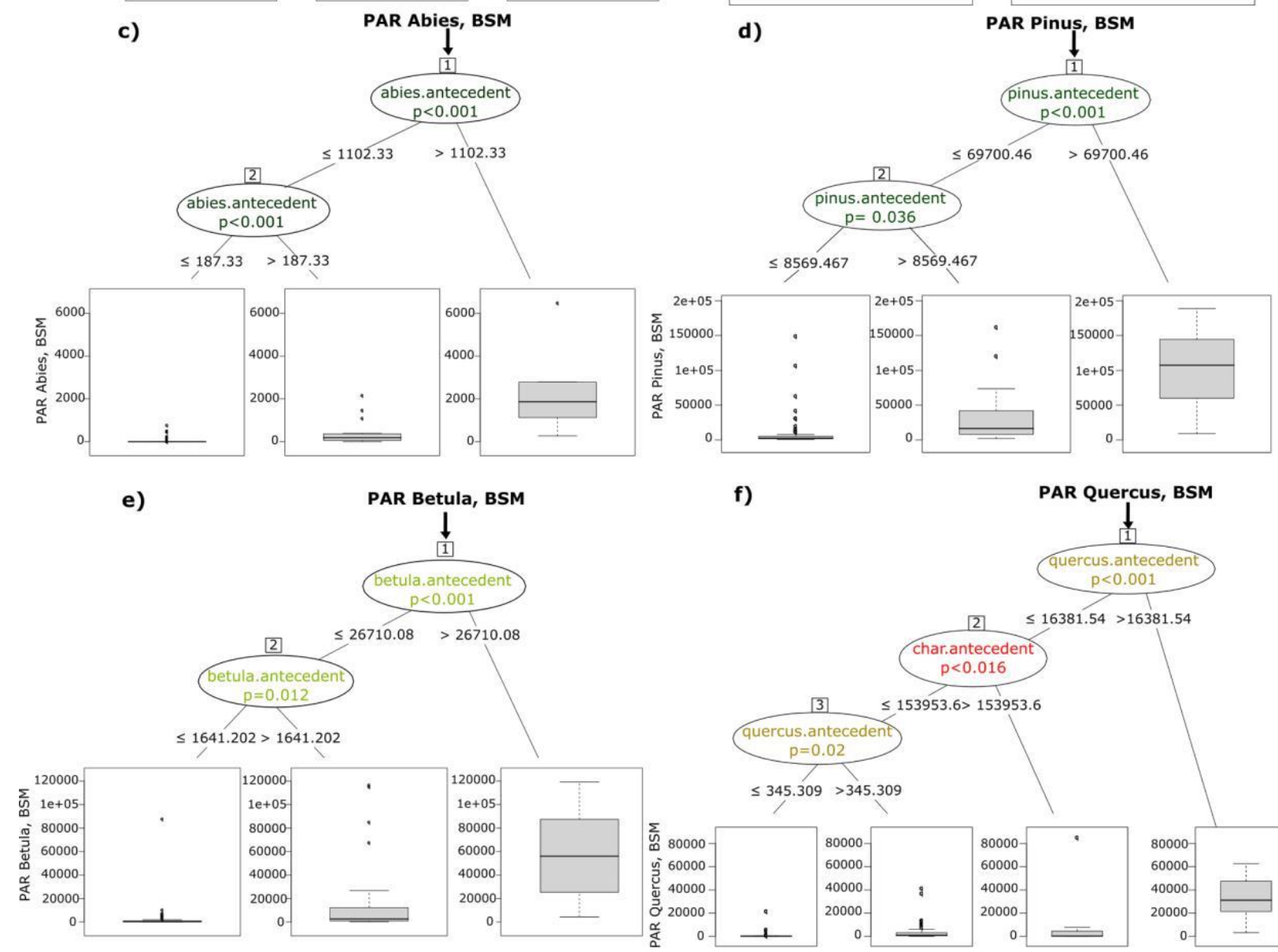

Figure 5. Conditional inference trees for selected taxa in both MAR and BSM sequences: (a) PAR Abies in MAR, (b) PAR Corylus in MAR, (c) PAR Abies in BSM, (d) PAR Pinus in BSM, (e) PAR Betula in BSM and (f) PAR Quercus in BSM. At the top of each regression tree, the initial PAR values for each taxa are indicated. Each of 1093 the circles (with a number e.g. 1,2,3) show the best explanatory variable (with the 1094 corresponding $\mathrm{p}$ value) from all the considered variables (CHAR, CHAR.antecedent or 

values of each PAR series classified according to the explanatory variables.

1097

1098
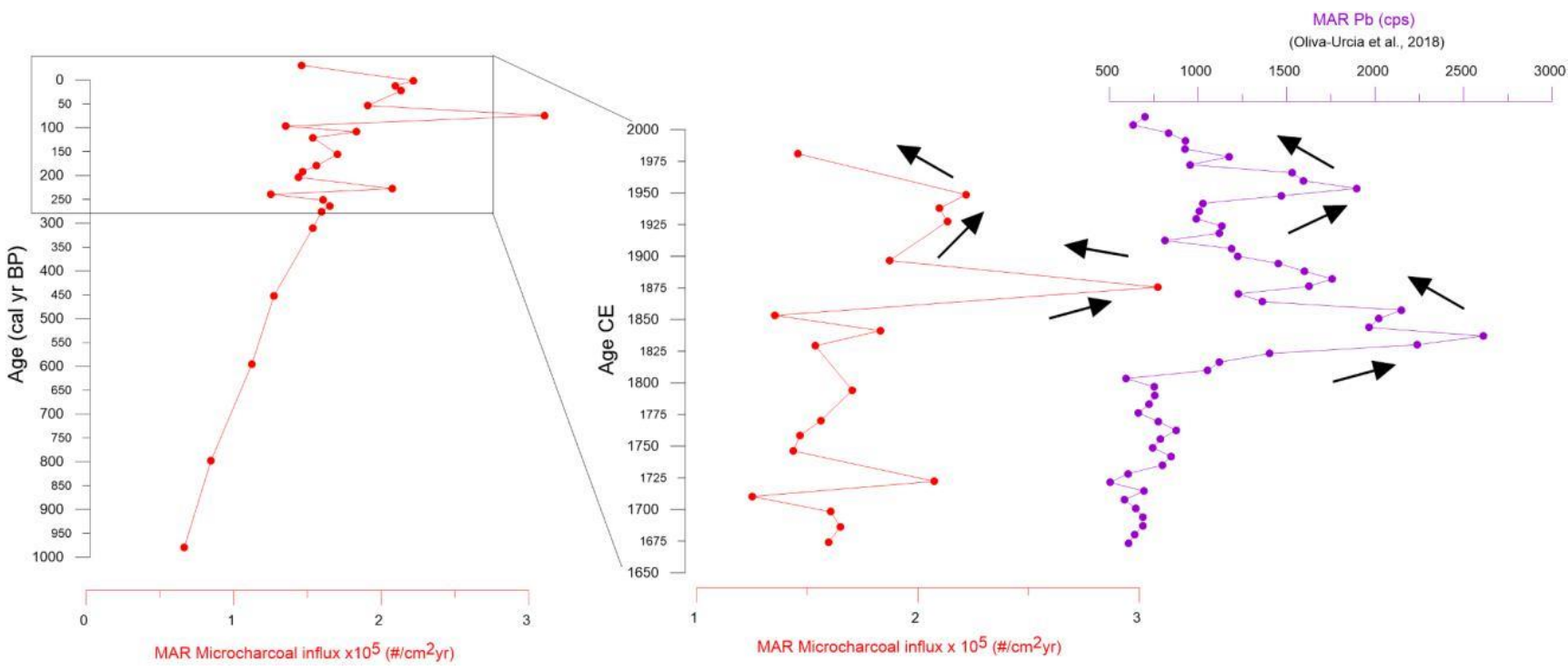

1099 Figure 6. Microcharcoal influx in MAR for the last 1000 years (left side) with a zoom

1100 over the last 300 years and compared it with $\mathrm{Pb}$ element profile (Oliva-Urcia et al.,

1101 2018) in MAR (right side).

1102 